DECLASSIFIED

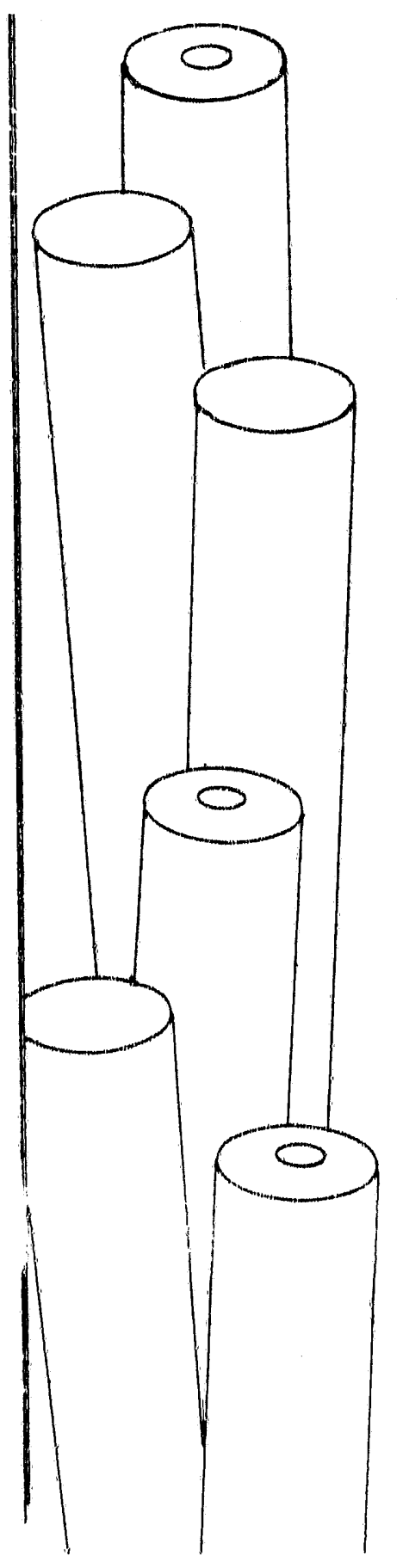

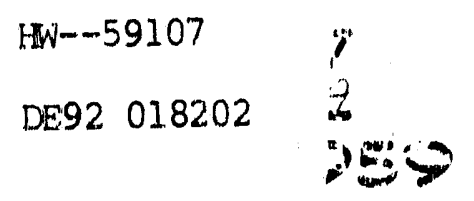

dIATEATI HBEs

\section{FUELS \\ PREPARATION \\ DEPARTMENT}

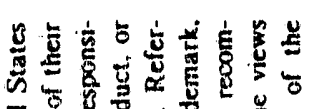

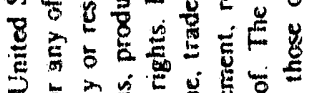

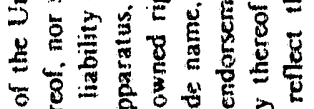

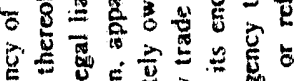

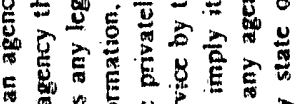

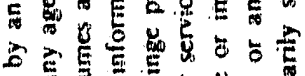

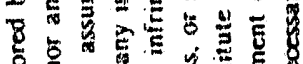

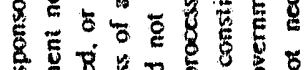

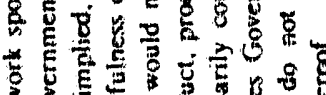

3

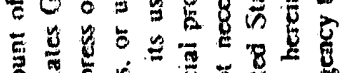

8ू

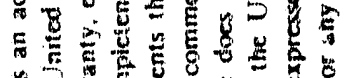

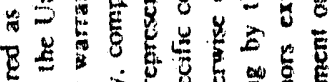

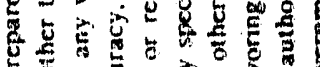

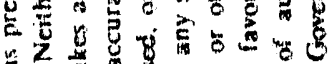

管

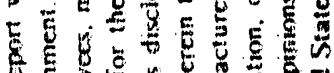

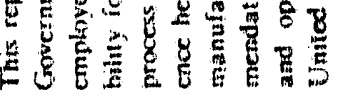

4
4
4

$1-4$

3

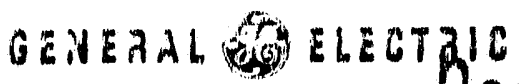$$
\text { Reperis: }
$$

$$
\text { AUGO } 31992
$$

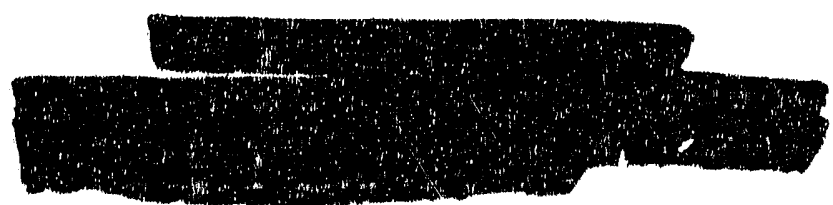

DECLASSIFIED

Mro? 


\section{HANFORD ATOMIC PRODUCTS OPERATION \\ RICHLAND. WASHINGTON}

\section{NOTICE!}

This report was prepored for use within General Electric Company in the course of work under Alemic Energy Commissicn Controst W.31.109.Eng.52, and any Vews or santions expressec in the teport ase those of the outhers only. This racort s subject to cevision uson collaction of additionol sato.

\section{LEGAL NOTICE}

This report was prepared as an account of Government sponsored work. Neither the United Steres, nor the Commission, nor any person octing on behalf of the Commission:

A. Makes any warronty or representation, express or implied, with pasest to the aceuracy, comlpleteness, or usefulmoss of the infermation containad in this report, or that the wee of any intormation,

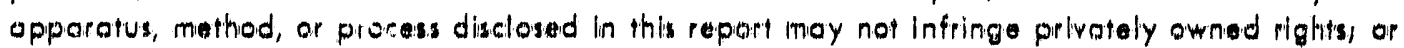

B. Assumes any liabilitiog with respect to the wse of, or for domages resulting from the use of any intormotion, apparatus, mothod, or process disclosed in this report.

As used in the ebove, "porson actimg on bahalf of the commission" includes any omployea or coritractor of the Commission to the extent the such amployoe or controctor prapores, handles ar distrib. utes, ar provides access to, any information pursuant to his umployment or contract with the Commission. 


\section{DEC - BartitD}

HW -59107

This document consists

5 , pages, copy no.

of 4 copies, Series

DECLASSPFED

By Authonty or. PR-24

DS Leduis is.25 -92

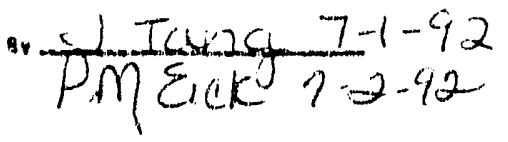

MONTELY REPORT

FUELS PREPARATION DEPARTMENT

Fuels Freparation Department

Febmary 23, 1959

Richland, Washington

\author{
FOR \\ JANUARY, 1959 \\ Complled by
}

a. ariag

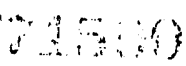

Work performed under Contrict No. W-31-109-Eng-52 between the Atomic Enerey Commission and General Electric Company.

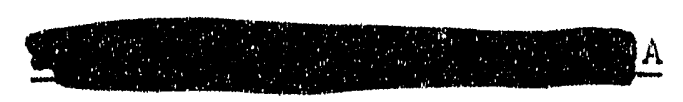

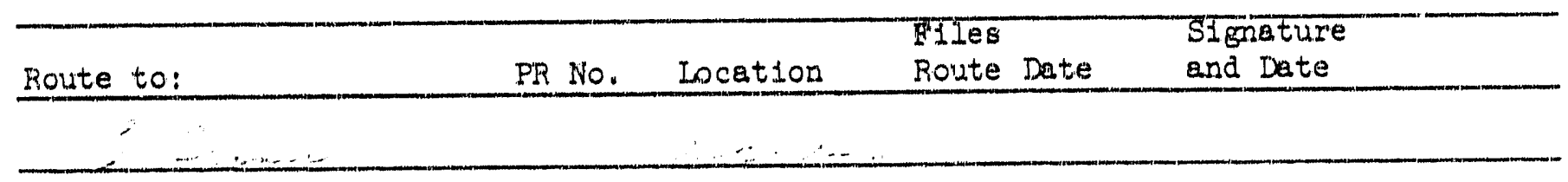

\section{DELAMNAT}

A- 1 


\section{DePinampt}

$H W-59107$

DISTRIBUTION

Copy Number

$\begin{array}{ll}1 & \text { W. E. Johnson } \\ 2 & \text { L. L. German } \\ 3 & \text { H. M. Parker } \\ 4 & \text { H. D. Tibbals, CEO } \\ 5,6,7 & \text { J. E. Travis, AEC-HOO } \\ 8,9 & \text { E. J. Bloch, Director - Division of Production } \\ & \text { Washington 25, D. C. } \\ 10 & \text { Sevannah River Operations Offlce } \\ 11 & \text { G. D. Barr } \\ 12 & \text { E. Hilgeman } \\ 13 & \text { W. M. Mathis } \\ 14 & \text { W. S. Roe } \\ 15 & \text { J. W. Talbott } \\ 16 & \text { K. V. Stave } \\ 17 & \text { H. .. Berg } \\ 18 & \text { J. T. Stringer- S. M. Gill } \\ 19 & \text { R. S. Paul - H. F. Zubr } \\ 2.0 & \text { J. C. W1lliamson . K. Drumbeller } \\ 21 & \text { Extra Copy } \\ 22 & \text { 300 Files } \\ 23 & \text { Record Center }\end{array}$

TABIE OF CONIENT'S

General. Summary

Manufacturing operation

Engineering Operation

Innancial Operation

Maintenance \& Power Operation

Employee Relations Operation
A-1 through A-5

B-I through B-11

C-1 through C-19

D-1 through D-5

E-1 through E-5

F-1 through F-6 


\author{
FUEIS FREPARATION DEPARIMENT \\ MONTHUY REPORT SUMMARY FOR \\ JAINUARY, 1959
}

\title{
MANUFACTURING OPERATION
}

Five hundred eight (508) tons of acceptable uranium fuel elements were produced which was $108 \%$ of forecasted production. The manufacturing yield for eight-inch I \& E fuel elements increased to $82.6 \%$ from $81.9 \%$ in December. This was the itfth consecutive month of yield improvement for eight-inch I \& $E$ material. Braze porosity was reduced by improving vibration of the canning jacks and by increased use of chloride heat treated cores. Also, improvements were made in component and finished fuel element cleanliness. Six-inch $I$ \& $E$ enriched fuel elements yield increased from $84.6 \%$ in December to $86.2 \%$ in January.

At month end there were eight hundred six (806) tons of bare uranium cores in storage. Finished fuel element invertories in combined 100-300 Area storage varied from about a three-month supply of eight-inch " $K$ " size I \& $E$ to a threefourth month supply of eight-inch "O" size I \& $E$ fuel elements.

No autocl.dve failure occurred in January coupared to one in December and four in November. Adoption of spire etch is largely responsible for this improvement.

The one millionth $(1,000,000)$ elght-inch plece was sent to storage during the week of Jaruary 5 climaxing a two-year transition period from 100 per cent solid production to essentially 100 per cent I \& $E$ production.

Culminating discussions of more than a year, the Narional lead Conpany of Ohio informed us that they are planning to ship enriched fuel element cores by truck rather than by the baggage car formerly used. This method will decrease shipping costs by almost two-thirds. The decision is based upon a series of criticality studies conducted by Mr. Callahan, at ORNL, in which he was unable to cause twelve tons of .94 enriched uranium to go critical regardless of the geometrical array even when submersed in water.

\section{ENGINEERING OFERATION}

The favorable trend in rupture frequency continued during January. This is attributed to: (1) changes made in reactor conditions, (2) the use of tighter bond test standaras, and (3) process changes initiated in the bond improvement program. The major cause of $I$ \& $E$ fallures is st1ll ron-wets. A number of these failures occurred in material charged prior to the initlation of process changes to reduce non-wets. About one-half, however, involved HAPO reheat-treated transformation reject cores. Preliminary measurements indicate that special closure problems and resultant faliures may be due to the warp proneness of this material. 
Thirty columrs of enriched I \& E elements, identified as to varying bond quality, were charged to evaluate the effect of braze voids hot spot corrosion. A previous test utilizing solid elements showed no correlation.

During January the first shipment of dingot metal was received. Certain variations frum standard were noted and corrective measures regarding heat treatment have been initiated with the vendors.

A study is undeway concerning methods for the casting of aluminum jackets directly onto uranium cores. If such a process is feasible and can be developed, it should result in substantial savings in components.

Four off-site coextrusion runs of uranium-zirconium have been scheduled. Material procurement, billet design, and preliminary fabrication is underway to assure completion on schedule. This work provides for continuation of process development and standardization pendine the completion of the coextrusion pilot plant at HAPO.

Several customers from outside the Department requested assistance in their nondestructive testing problems. Some of the programs initiated for their aid include: (1) development of nondestructive methods of testing plutonium specimens for porosity and internal defects, (2) measurement of resin levels at the interfaces of CPD liquid columns, and (3) development of ultrasonic vibration method for liquid aluminum melts. Nondestructive studies in support of the 4000 program continue to show promising results. Completion of the first phases of the broad band eddy current and the ultrasonic lamb wave studies indicate that: results of the former will lead to a better solution for I \& E internal testing; results of the latter can be applied to unbond detection and bond strength measurements.

\section{FINANCIAI OPERATION}

Inttial procedures for an integrated ledger system are substantially complete and drafts were forwarded to Data Processing for review. A Data Processing representative is to be assigned next month to begin actual prograning. Work to date is on schedule.

Productivity Report for calendar year 1958 was issued this month. Compared with 1957, productivity increased $37 \%$ due principaliy to yield inprovement and cost reduction programs.

Major changes in financial reporting were implemented this month which incorporated the Company wide practice of responsibility reporting; $1 . e .$, only costs which a component directly incurred were reported to that component. Functional cost re." ports (production, mintenance, power, etc.), of course, include total costs regardless of where or by whom incurred.

Requests for information required for the revision of the FY- 60 budget and for preparation of the FY-6I budget, were made early in Fanuary. Data furnished level 3 Operations Included actual costs for the first a1x montbs of FY-59.

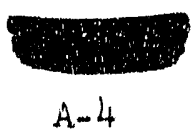

A- 4 


\section{MAINTENANCE \& POWER OPERATION}

Addressographing of mail on distribution lists is now being done by the Duplicating and Meil facility, with no additional manpower being required. This move results in expediting delivery of mall of this type by twenty-four hours.

A micro spark source unit was completed for use by the Analytical Laboratory Operation. This instrument is capable of analyzing areas of 2 to 5 microns and will be used to study fuel element inclusions.

The injection rate of the filming amine in export steam to the lab area has been held at the initial 5 ppm.

On January 20 swing shift contractor personnel working in the PRTR construction area discarded burning, smoking material which landed on a pile of concrete curing pads and canvas tarps. The fire was located sixty feet down on the inside of the vessel and was just extending to the wood forms and shoring when discovered.

\section{PERSONNEL STATISTICS}

Number of employees December 31, 1958

Number of employees January 31, 1959

753

750

OPERATION

General

Manufacturing

Engineering

Financial

Maintenance \& Power

Employee Relations

TOTAI
EXEMPT

1

54

50

15

38

10

168
NON-EXEMMPT

TOTAL

$27 \frac{1}{6}$

25

1.6

255

9

582

750

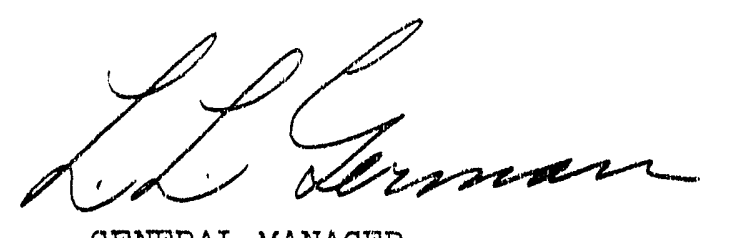

GENERAI MANAGER

FUELS PREPARATION DEPARIMENT

LLGerman/ jak

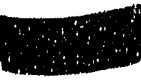

A- 5 
MANUFACTURING OPERATION

January, 1959

I. CURRENT OPERATIONS

A. Production and Productivity

1. Statistics

Current Month's Production

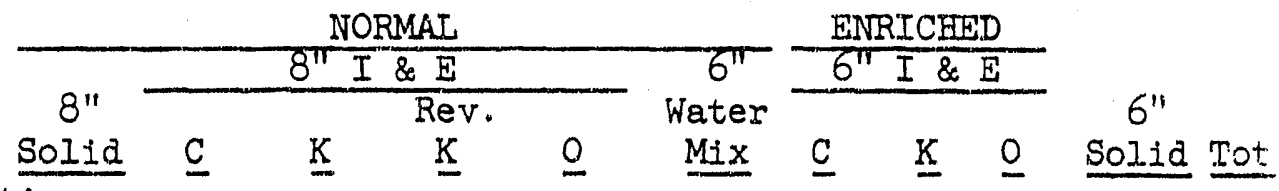

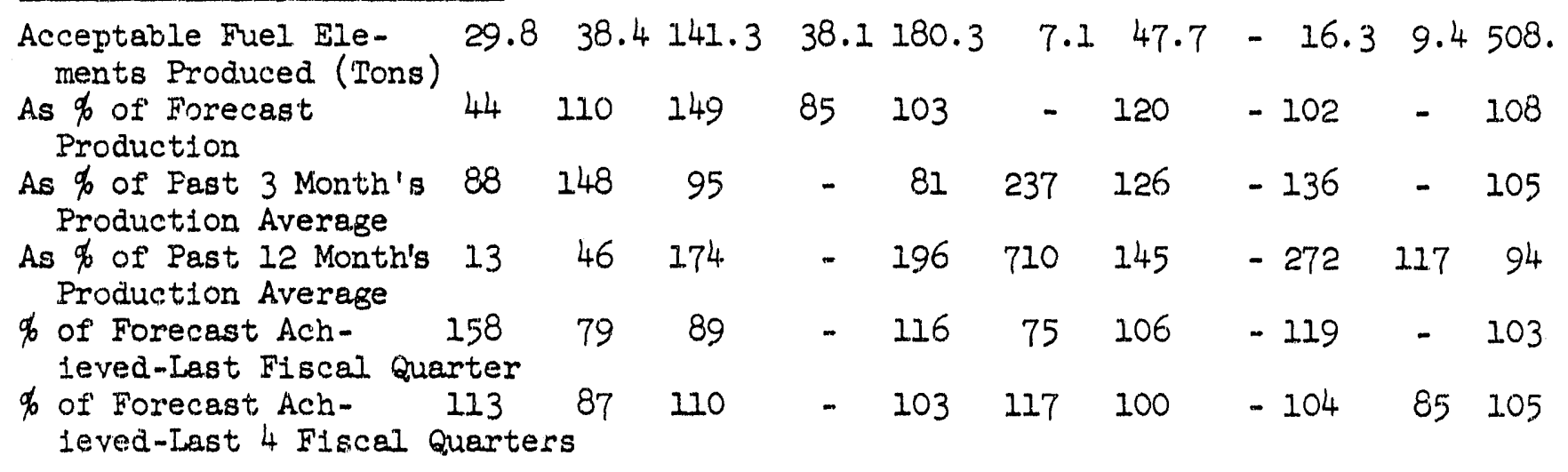

Operating Efficiency

Current Month ( $\%)$

Forecast ( $\%)$

93.

Previous Month ( $(\%)$

Manufacturing Yiela

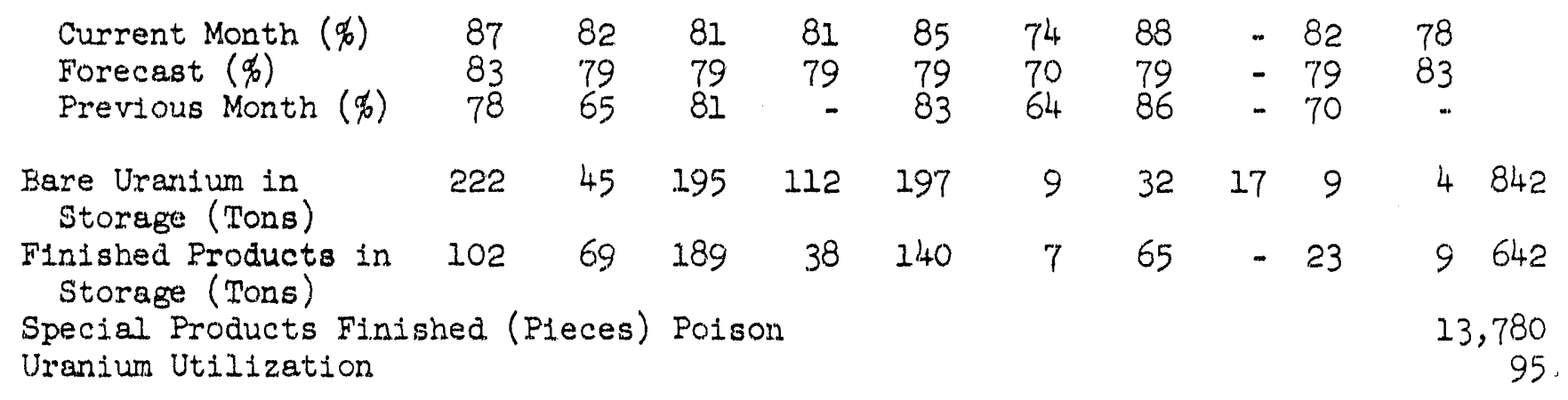




\section{Activities}

a. Production

January fuel element production was five hundred eight (508) tons, or 108 percent of forecast (HW-58066). Extra production resulting from higher manufacturing yields and operating efficiency enabled the curtailment of six canning line-shifts during the month. The released manpower was profitably utilized to operate the salt bath heat treat facility thereby reducing accumulated transformation test reject material. Except for this brief curtailment, the plant operated elght canning lines each day, four canning lines per shift.

A milestone for fuel element production was reached during the week of January 5 when the one-millionth eight-inch I \& $E$ piece was sent to finished storage. In the short period of two years, a transition has been made from the production of solid fuel elements to an essentially 100 percent production of $\mathrm{I} \& \mathrm{E}$. As a measure of the advances made during this period of change to the processing of the more complex I \& $E$ fuel elements, productivity measured in finished pieces per operator-month has increased about 23 percent. The output measured in finished tons of uranium per operator-month has increased more than 11 percent in the same period.

b. Yleld Control

\section{December Yield Junuary Yield}

8" I \& E
8" Solid
6" I \& E
6" Solid

$\begin{array}{ll}81.9 \% & 82.6 \% \\ 78.1 \% & 86.5 \% \\ 84.6 \% & 86.2 \% \\ & 78.7 \%\end{array}$

This was the fifth consecutive month of yield improvement for elghtinch I \& E pieces from a low of 73.3 percent in September 1958. Yield galns were reallzed through improved braze porosity, component cleanliness, and surface quality of linished fuel elements. These gains were partially offset by a small rise in the thin wall reject rate.

Braze porosity was reduced as a result of improvements in control of canning vibrators. The amplitude and frequency of vibration was increased through replacement of wurm vibrators and adoption of an improved preventive malntenance program for the vihration assembly. Also, a higher proportion of the uranium cores had beeis leat treated by National Lead in chlorlde salt. These contained less hydrogen than cores heat treated in carbonate salt, and thus minimized undesirable outgassing effect on braze porosity.

The surface reject rate dropped to a new low of 0.3 percent compared to the 1958 average of 1.8 percent. This consistent gatn can be attributed to better control of cleanliness at component preparation and final steh.

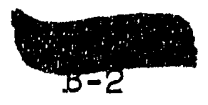


b. Yield Control - continued

The yield for six-inch enriched I \& $E$ fuel elements was 86.2 percent compared to 84.6 percent in December. Significant improvements were made in reducing braze metal contamination and weld rejects largely through control of cleanliness at component preparation.

No autoclave failure occurred in January. These failures have been a problem generally throughout 1958. January improvement is attributed to the adoption of the spire etch process that promotes better cap wetting by effectively removing oxides from the bonding surfaces.

\section{c. Other Activities}

Seven and one tenth (7.1) tons of six-inch water mix pleces were transferred to finished storage. All of this material was canned in December but held in process until the arrival of water mixing spools. It is estimated that a one-month supply of these pieces now exists in 300 100 fintshed storage.

Eight thousand seven hundred ninety-seven $(8,797)$ pb-ca (lead poison) pieces were assembled, and thirteen thousand seven hundred elghty $(13,780)$ pieces transferred to finished storage this month.

About five thousand six hundred $(5,600)$ eight-inch I \& $E$ canned pleces originally rejected for minor weld bead defects were reclaimed by machining off the orlginal weld and successfully rewelding.

Bare uranlum pleces avallable for canning continued at about a one-month supply although a wide variation in specific product supplies exists. Bare inventory of efght-inch solid pieces is particularly high at about a three-month supply while old pile and "C" pile eight-inch I \& E bare pieces are down to about a three-fourth month supply. Planning and scheduling discussions are continuing with the National lead Company to improve the inventory balance.

Finished uranium inventories in combined $300-100$ area storage were adequate during January. However, finished supplies of eight-inch old pile I \& $E$ pieces were at a minimum at month end. Consumption of this product has exceeded expectations somewh at since it is being charged further into reactor fringe areas than orlginally forecast. The short supply of bare old pile I \& E pieces has prevented a build up of finished inventory.

Higher manufacturing yields currently being achieved have enabled Fuel Recovery to keep the quantity of reject fuel elements awaiting recovery to a minimum, even though some outage time due to equipment difficulties was experfenced. At month end 4,000 pieces were backlogged awaiting recnvery. This is less than two days min. 
c. Other Activities - continued

The followlng pieces were processed through the Fuel Recovery Operation.

\begin{tabular}{lr} 
& Pieces \\
8" Solid "O" & 727 \\
8" I \& E "" & 12,240 \\
8" I \& E "C" & 4,061 \\
8" I \& E "K" & 9,880 \\
8" I \& E "KR" & 2,106 \\
Water Mix & 84 \\
\hline
\end{tabular}

Two scrap shipments containing 137,573 pounds of normal and 3,655 pounds of enriched uranium scrap were returned to National Iead Company during the month alone with 900 empty fuel core boxes and three barrels of uranium oxlde from Hanford Iaboratories Operation.

A shipment of 160 barrels of depleted uranium scrap was received from Rocky Flats, Colorado on January 29, 1959 and was buried in the Hanford Laboratories North Burial Grounds.

\section{B. Plant Problems and Incidents}

1. General

Operating efficiency was 94 pernent as compared to 94.8 percent in December and a forecast of 93 percent. Outages were split almost evenly between operational and equipment causes.

\section{2. $\mathrm{CG}-713$ Assistance}

Manufacturing Maintenance labor has been applied to Program CG-713 as requested with functional guidance provided by the project engineers. Two new canning quench iuachines were installed and are operating satisfactorily. CG-713 work is being given top priority so that equipment trial runs can proceed. Postponement of other committed manufacturing maintenance work has resulted.

\section{Component Quality}

Purchasing agreements probably will soon be established with all aluminum component vendors where the vendor w1ll certify the dimensional and visual quality of the component shipments. Historically these have been sampled and analyzed at HAPO to assure that the material met specifled quality levels. If these levels were not met, the material has been sorted at our expense. In an effort to induce the vendor to improve control of component quality, quality levels will be written into the purchasing agreements. If materials fail to meet these requirements, the shipment will be returned to the vendor or sorted locally at his expense. These

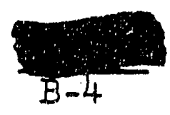


3. Component Quality - continued

agreements have been successfully negotiated with the Harvey Aluminum Company and the Hunter Douglas Corporation and the procedure has been established on a six months trial basis with Alcoa, the principal supplier. These vendors are now perfecting in-plant procedures to duplicate HAPO measurement techniques and to refine their in-process quality control systems.

Recently it was determined that slight dimensional distortions of the canning sleeves would result in disturbance of braze metal flow characteristics and excessive loss of cladding thickness. To effect immediate quality gains the use of all sleeves was reduced to 25 cycles when supplies permitted. The 25 cycle limit is probably "safe" for most sleeves but optimum cycle life seems to vary between vendors, lots from the same vendor, and product type. A need exists to develop measurement methods to determine when sleeves should be removed from service and efforts are under way to correlate various sleeve measurements to special fuel element yield and quallty measurements.

4. Core Quality

Additional studies have been made of the core transformation salt bath operation at HAPO. These studies have been directed toward reducing core warp and preventing core absorption of hydrogen. The stuaies have shown that a vertical quench in quiescent water will not prevent warp. Apparentiy the steam pockets formed around the core immediately after inmersion prevented even cooling. As a result the quench prosedure has been changed to require lateral movement of the core in the water to sweep these steam pockets away from the uranium. It has also been demonstrated that water pickup by chlorlde salt will result in increased braze porosity and methods for controlling water pickup are being evaluated. In conjunction with these investigations it has been shown that cores originally transformed in blank form in chloride salt are less prone to warp from adiditional heat treating than cores originally transformed in rod form in carbonate salt.

Investigation of the present sampling plan for the reaeiving inspection of virgin uranium corse had indicated that a reductior in sampling and measux ing effort of about 60 peresnt car be made through tine use of a new samplire plan that incorporates reduced inspeztion levels when a condition of suitaire: high quality level is being experienced. This plan involves no change in acceptable quality levels and will be tried on a test basis besinning in Febmuary.

5. Non-Destructive Testing

Recently pile failures aue to water penetration into the $I$ \& $E$ fuel element bore have increased. Also, an increase in severity of exposure to this surface has been prodicted. As a result ir vestigations have been initiated for improving the quality assurance of the intermai. bore of the I \& E fuel element by non-destructive testing.

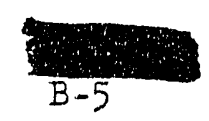


5. Non-Destructive Testing ".. continued

Historicaly all I \& E fuel elements have been processed through the internal penetration tester which was designed to reject fuel elements with insufticlent: cladidng thickness in the intermal bore. However, this test has been extremely censitive to any bump, wrinkles or volds. As a result the test has not been used as a final determination of acceptable cladding thiciness but has teen used to supplement destructive test measurements and process controls for deteimining acceptability.

Acceptability for braze porosity has been determined by procegsing all fuel elements through an internal bond tester culiturated to rafect any fuel element. wh th a single vold greater than $0.75 \mathrm{~cm}$. measured in a circurerential d. rection. Eramisation of these volds has often shown that the longltudinal dimension is greater than the circumperential. Bowever, it has not been poratble to apply the memory count test to the intermal surface because of spurious counts induced by electronic and mechemical difficulties. Also, ais previougly polated out the voldis interfere with utidialng the intemal penetration teiter for acceptance of cladding thickness.

In conjunction with Testing Method a progrem ha beel developed to determine if the outgoing quality level can be larproved and both internal testers uged as acceptance tests. The program 1ncludea evaluation of the quality and vi..ld effects from tightening the internal bond test standard from $0.75 \mathrm{~cm}$. to $0.5 \mathrm{~cm}$. It is feit that this change shoula reduce the number of long narrow volis acceptec and may subtract some of these from the internal. penetration test category. Also, supplementary electronic equipment for reducing the sensit1yly of the intermal perietration test to burmo and wrinkles is being evaluated.

\section{Dingot Materizal}

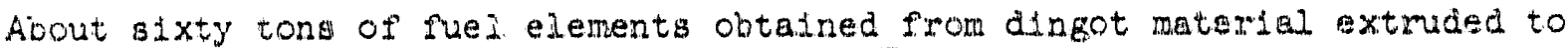
ingot size before rolling were recelved. The shiprent marked tibe first of this raterdel acheduled to be recelved at about fifty tons per month. Evaluation of the initial shipment revealed a lack of uniformity in enain size, bratn orientation anc a hyarogen content rangine up to 6.5 ppin instead cf the specified 5 ppm upper limit. The Pliot flant runs were bedne mase at moth and to assess the effects of these conations or braze porosity and core stability. Meanwile, our auppliers have been advised not to sinl? more dingot mater1al until setisfactory process methode have been estrablished.

\section{Operating Plans}

1. Renctor Requirements and Production Schedules

The followne coments based on a review of reactor requiremente and

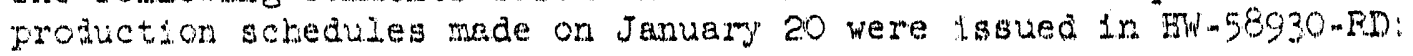

\footnotetext{
"Due tc a relaxation of restrictions in the operating conditions istablished by the Adrisory Comptee for Reactor" Safeguards, some planed reductions in exposure levels for normal urantum I \& $\mathrm{E}$ flel elenert: will not be as great as previously forecat.
} 
1. Reactor Requirements and Production Schedules * continued

"Consequently, for the remalnder of FY 1959, reactor" requirements for normal uranium w11 be ahrat 11 percent below those contained in the previous forecast. During thils same perlod, however, exposure levels were forecast to be reduced for the enriched I \& $E$ fuel elements. This, plus a decision to increase residual reactivity in the reactors, increases reactor requirements for enriched uranfur by 2 percent over the previous schedule for the remainder of FY 1959.

"Finished production of normel fuel elenemta will decrease only 6 percert from the previous schedule for the balance of 171959 , enabling an increase in the findshed inventory lavel. Prokuction of enriched fuel w11 increase 26 percent to correspond with the wigher reactoz" requl rements.

"The operating" plan for" the current schedule requires continuous operation of esght canning IInes dally on a twomshtet flve-may week babia. Bectuse of che increased production of enriched fuel elements, four overtime say's are planned during the and Quarter and three overtime days in the 3rd Quarter, Fy 1960. A total of 16 overtime days is forecast for IF 1961. Operating efficlency of the caning lines 1 is forecast at 93 percent throughout the periog."

2. Bumper and Self-Sugported Fuel Elements

Thts program is being instiated in an effort to reduct the frequency of the hot-spot type rupture in the reactors. Since the indtial charges of this type material are currentiy in the preparation stage, fluture program scope is rather nebulous at this the. The minon scale tests scheduled to be chared 10 the next few montha wil utdidze material produced on a development basis by the Engineering Operetion. It is understood that a new welding mechine is now being procured by ngineering. It was

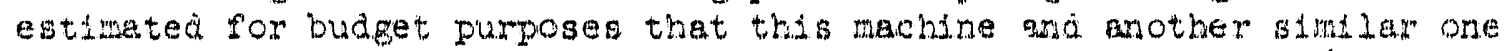
vould be avallable for production use by the 3rd aturter Fr 1960 . These machines would be utilized to produce the materien reguined to tarm ont lareer scale testes and should enale up to 15 percent of the totai pan. duction of ruel elenents to be supplied inth burners on support.

3. Enriched Shipment by rymack

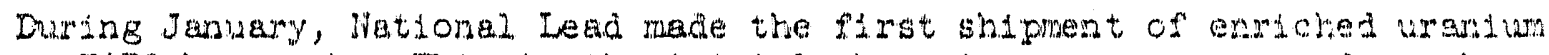
to BAFO by truct. This is the enteial phase in a program to reace vie high shipping costs presentiy being inourred on enriched uramiun. In the past, a major pert of enriched uranium recelpts was sent by express at a cost ot more than $\$ 23$ per mindred pound.s. Truck rates wild be about \$i. 50 fer hundred which 1 s a reduction of almost two-this i from express costs. The decision is based upon a series of criticality studies conducted by Wr. Callahen at Oeir Ridge Mationel Laboratory in which re was wrable to cause twelve tong of 94 enriched urandum to go natical regardess of the geometrickl aray even when submersed in whter.

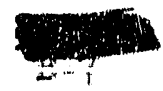


4. 306 Pilot Plant

Equipaent modifications and new arrangements were made in the 306 canning line faclifties so that they will more exactly correspond to conditi ons existing in the 313 Building. Canning jacks, thermccouple and other furnece accessontes were involved. It is expected that test results may now be more accurately compared to existing 313 Bullding process conditions.

The welder used to attach aluminum spools to water mixing pleces was removed from the 306 Pliot Plant to the 313 Buliding weld laboratory. This move is one phase of an over-all program to release approximately one-third of the present floor space for co-extrusion development.

5. Manpower Requirements

The adoption of several. new programs and activities sirce mid-year budget review time has made 1 t necessary to retain manpower, and in some cases to step up hiring plans. Specificaliy: (1) four operators were retained to handle the spire etch operation which has proven very Buccassul in improvIng I \& E cap wetting; (2) reducling the cycle life of steel sleeves to approximately $25 \mathrm{has}$ created a need for one adalional operator at the aleeve preparation atation; (3) Hanford Laboratories stepped-up developrant programs in the 306 Bullding has created need for Manufacturing Maintenance assistance earlier than expected. Consequently four men formerly bcheduled in the 4 th quarter wili be hired in the $32^{4}$ and three men scheduled for hire in the first Quarter of IN 1960 will be hired in the 4 th Q

(4) adoption of a cooperative quality assurance program involving IFD and IPD personnel may make it necessary to thire about five individula before the end of this flacel year for the Quelity Control Operation.

\section{Security Measures, Uraniurn}

On January 2, arrangements were completed by the Materials Operation for the discontinuance of a patrol escort for enricher uranium shiphents to the 100 kreas. Concurrence was obtained to adopt this proposal frot both General Electric and AEC Security. Also, the procedure of placing metal seals on uranium storage bing and buldaings in the 303 Area for security purposes, was asscontiried on January 2. In the future beals will be used for accourtability jurposes, whenever appropriate.

\section{Bmployee Relations}

\section{Safety Ferformance}

Wembers of the Operation were treated for 14 medical treatment infuries for a frequency of 2.50 .

During the month, a lost-time 1 dury was incurred when an operator in fued Recovery was splashed in the eye wis th actium nydroxide from one of the recovery tanks. There was no permanent injury to the eye and the operator hals returnes to work.

2. Radiation Control

Greater than 300 mrada

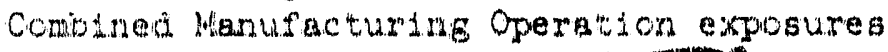

December 1958

1 badge

3,203 mrads
Januan 1959

No badges 5,301 mrads 


\section{Radiation Control - continued}

Radiation exposure for Manufacturing Operation personnel, as measured by film badge results, remained within control limits.

\section{Security Violations}

No security violations were reported in January.

\section{PERSONIEL MATTERS}

\section{A. Reports of Invention}

Members of the Operation engaged in work that might reasonably be expected to result in inventions or discoveries advise that, to the best of the ir knowledge and belief, no inventions or discoveries were made in the course of their work durine Januery 1959.

\section{B. Meetings}

Members of the Operation attended 19 staf' meetings, 14 saisty and security meetings and 11 intormational meetings.

\section{Visits and Visitors}

D. G. Kern visited Mr. C. H. Wright, Cliff Manufacturing Company, Wickliffe, Ohio on January 1.3 to discuss problems associated with manuf"acture of aluminum componen.

On January 14 Messis. K. V. Stave and D. G. Kern visited with $M_{n}$. W. W. Spencer, Manufacturing Serwces, New York City to discuss Quallty Control matters, and on January 25 and 16 they visted $\mathrm{Mr}$. A. R. VanVorst, Alcoa in Edgewater, New Jersey to discuss proinlems associated with the manufacture of eluminum components.

i. G. Tews attended a meeting of the AEC Metaliographic Group held at Armour Besearch Foundation of Illinola Institute of Technology in Chicago, Iilincis or. Januery 24 and 15.

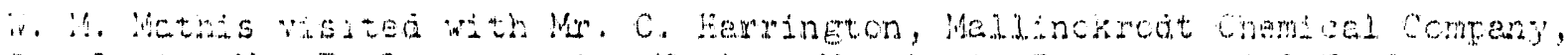

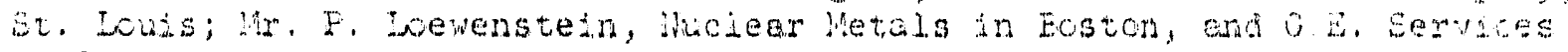
in schenectad to discuss tuel element technology, fabrication and manufacturang technsques.

K. V. Stave risited in Seattle, Washington to recruit bsilus candidates in eneinewring and acience at the University of Wasington and Seattie Univeraty on January 26,27 and 28.

I. Sipuficant Reports Issued

1. Folitine

\begin{tabular}{|c|c|c|c|}
\hline Bumicer & Ty & sutros & Dare \\
\hline Fin- $546+6-R D$ & 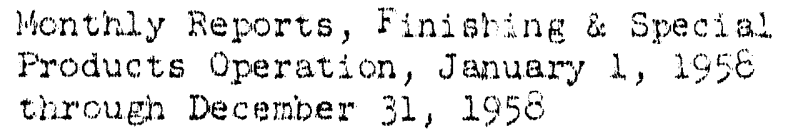 & nc Woney & \\
\hline
\end{tabular}

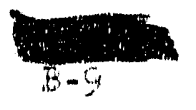


1. Routine Reports Issued - continued

\begin{tabular}{|c|c|c|c|}
\hline Number & ts.tle & Author & Date \\
\hline $\mathrm{HW}-58720$ & General Analytical Program I & GB Hansen & $1-2-59$ \\
\hline HW -58727 & $\begin{array}{l}\text { Monthly Report Qurlity Control } \\
\text { Operation, FPD, December } 1958\end{array}$ & KV Stave & $1-2-59$ \\
\hline$H W-58736$ & Uranium Quality Analytical Results & GB Hansen & $1-5-59$ \\
\hline HW -58995 & Uranium Quality Analytical Results & GB Hansen & $1-23-59$ \\
\hline \multicolumn{4}{|l|}{ Non-Routine } \\
\hline $\mathrm{HW}-58887$ & Etched I \& E Spire Wafers & DD Stone & $1-14-59$ \\
\hline EW-58957-KD & $\begin{array}{l}\text { Production Assumptions and Operating } \\
\text { Plans Fuels Preparation Department, } \\
\text { January } 1959 \text { through June } 1964 .\end{array}$ & HE BerE & $1-22-59$ \\
\hline
\end{tabular}

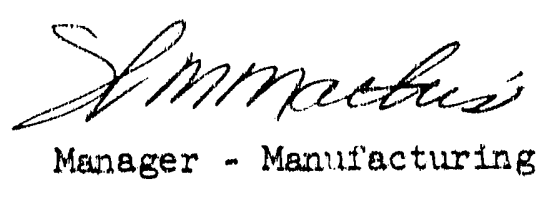

WM Math1s:RhM: rhs

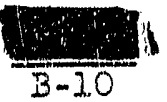




\section{YIELD STATISTICS}
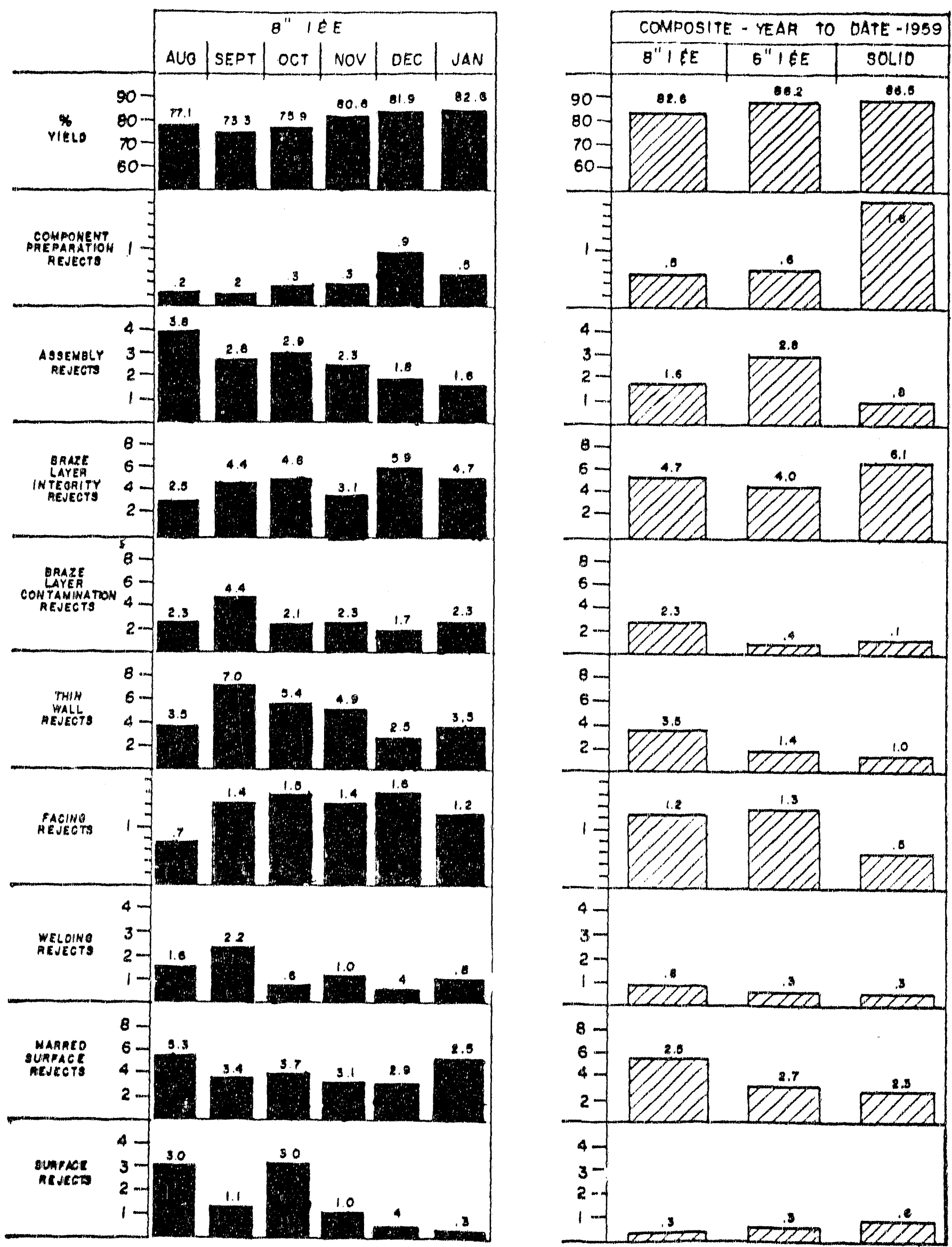


\section{ENGIXIEERING OPERATION \\ January, 1959}

VISITORS

Name

WH Hannah

$\mathrm{J}$ Wessel

CW Polson

JA Pellows

CE Bussert

$R$ Legasse

TRIPS

\section{Jistinger \\ JE Bergman \\ JE Bergnan}

AE Guey

TW Gore

IFF Zubs

JW Taibott

\author{
Comparay \\ Puget Sound Naval \\ Shlpyard \\ Bremerton, Wash. \\ National Lead \\ Mallinckrodt \\ National Lead \\ OROO
}

\section{Company Visited}

Savannain River

Ga.

\begin{tabular}{|c|c|}
\hline Contact & Date \\
\hline $\begin{array}{l}\text { BS Palul } \\
\text { HI Iibby }\end{array}$ & $1-19$ \\
\hline $\begin{array}{l}\text { JT stringer } \\
" \\
" \\
"\end{array}$ & $\begin{array}{l}1-29 \\
1-28 / 29 \\
1-29 \\
1-29\end{array}$ \\
\hline
\end{tabular}

$-$

Alcoa, Edgewater, N.J.

Armour Research
Poundation,
Chicago, III.

Bumstead \& Woolford

Seattle, Wash.

TC Evans

$1-13 / 15$

$1-13 / 14$

AR VanVorst $1-15 / 16$

RW VanThyme $1-14 / 25$

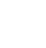

Attend 13th Annuel

$1-15 / 16$

Mellinckrodt Chemical

C Farrington 1-19

Ga-Refrig. Dept. H Disco $\quad$ L.20

Louisville, Ky.

Nuclear Metals, Inc.

Concord, Mass. P Lewenstein 1-21.

GE-Gen. Eng' B. LaU.

Schenectady, N.Y. ZD Sheldon $1-22$

BP Zwhr
GR-Research Lab.

Schenectady, N.Y. DW Lillie 1-23

National Lead, Co., A Stevart 1-23 Albany, K.Y. Heeting of the AEC

Meterlography Group

Reason

Discuss eddy current methods of nondestructive testing plpe and tubing

Discuss uranium technology "

13

Attend Working Conmittee of the FrDC

Component procurement

Consultation on Project CG-759

Discuss uranium fabrication

Discuss metal fabricatio:

Discuss cladding technOIOEY

Discuss fuel element technology

11

11

Discuss uranium fabrication 
TRIPS (cont'd.)

Name

HF Zubr

Company Vislted
dufont
Wilnington, Del.
duPont
Augusta, Ga.

Contact

$J$ Woodhouse

A.A Johnson

Nat Wahl
Date

$1-26$

$1-27 / 28$
Reason

Discuss fuel element technology

PERSONNEI

$\begin{array}{lllll}\text { Name } & \text { Title } & \text { Operation } & \text { Nature of Change } & \text { Date } \\ \text { TB Correy } & \text { Engineer } & 4440 & \text { Transferred from } 4430 & 1-19 \\ \text { KR MCQueen } & \text { Draftsman } & 4480 & \text { Terminated } & 1-2\end{array}$

\section{PROCESS ENGINEERING}

Regular Product1on Rupture Experlence

Four normal uranium ( $I$ solid and 3 I \& E) fuel element fallures occurred in the reactors during January. In addition, two I \& $E$ depleted uranium failures were sus tained. A sumary of the ruptures is outlined below:

Puel Element Type

Solid Normal

I \& E Normal

I \& E Depleted

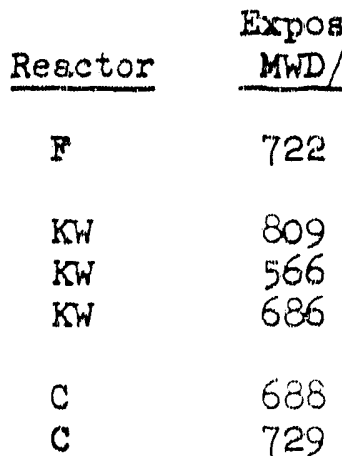

729
Rupture Classification

Unclassifled

Internal

Internal

Unclassified

Internal

Internal
Jacket Alloy

c -64

c -64

$x-8001$

$x-8001$

A continued favorable trend in rupture frequensy is attributed to lower reactor operating temperatures, reduced variable goal exposures for enriched material, and probable effects of tighter bond test standards and process changes to minimize brittle bonding on fuel element integrity. The najor failure category for I \& $E$ continues to be internal ruptures, which presumebly results from non-wets and porosity in the cap closure. One-half (5) of the I \& E nornal uranium I \& E internal failures hrive involved HAPO reheat treated transformation reject cores. Based on preliminary measurement data, this material is more prone to warp and may tend to aggravate the closure problem.

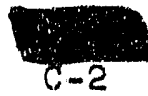


IPD Iiaison

The ACRS limits, restricting reactor power levels to the maximurn attained previously, were relaxed during the month. Steps have already been taken by IPD to raise power levels in the order of $5-10$ per cent, anticipating that all reactors will be operating on $93 \mathrm{C}$ bulk limits by sumer.

A rough draft of the CY 1959 Category I production testing schedule, prepared in cooperation with IPD and HLO representatives, is circulating for review prior to issuance.

Dimensional stability problems were experienced on "O" size I \& $E$ fuel elements during the month. One out of seven stuck charges has been measured to date, showing a maximum warp of $60 \mathrm{mils}$. In order to facilitate a review of the fabrication history of this material, caps wlll be removed to obtain ingot numbers stamped on the ends of the cores.

IPD has outlined a proposed program for bumpers and self-supported I \& $E$ fuel elements, based on ability to modify charging facilities and replace existing process tubes with ribless zircaloy tubes.

Target material has been recelved for cladding development and the preparation of 1,000 acceptable pleces for a proposed demonstration looding.

\section{I \& E Program}

An unexplained incidence of stuck charges has occurred recently, involving "O" 3ize I \& E normal uranium fuel elements. To date eight charges ( 4 in $\mathrm{H}, 3$ in $D R$ and $I$ in $B$ ) have required abnormal discharge pressure. Examination of the first stuck charge bas been completed in $C$ Basin, and one fuel element (\#6 position from upstream end) which warped a maximum of $60 \mathrm{mils}$ had bumps $4-6 \mathrm{mils}$ in height on the surface. This fuel element is scheduled to be examined in the Radiometallurgy Laboratory to detemine if anomalies in uranium core stmacture may have contributed to instability and bumping. Examination of the other stuck columns will be completed early next month in $\mathrm{C}$ Basin. Ingot numbers will be cotained from the ends of the cores showing maximum warp to facilitate investiga.. tion of fabrication history.

Thirty columns of enriched I \& E fuel elements, characterized by bond quality, were charged in $C$ reactor to further evaluate the effect of braze volds on the incidence of hot-spot corrosion during irradiation. A previous test on solid fuel elements showed no correlation between braze volds and hot-spots.

\section{Depleted Failures}

Two I \& $\mathrm{E}$ depleted fallures sustained this month increased the total experienced on a test to produce high Pu-240 product to thirteen. Because of the rupture proneness of this material, all of the remaining test pieces have been discharged from C reactor except eight replacement charges prepared using a caustic etchant on the caps. It is planned to irradiate this material for a prolonged period to probe the effect of the cap etchant on closure integrity. 


\section{DECLASSFIED}

$\mathrm{HW}-59107$

\section{Uranium Technology}

During January, the first shipment of dingot metal was received under HAPO's current agreement to accept up to 50 tons per month with 5 ppm hydrogen or less heat treated in chloride-blank form.

On metallographic examination of samples of the material, considerably larger than normal grain sizes were observed. In addition, considerably larger variations in grain size were noted within pieces and between pieces. Thorough examination of about 120 samples reverled that the varlations did not appear to be dingot related, but appeared to be possibly related to processing variations at FMPC .

In addition to the grain size variations, unusual and larger than normal variations were observed in the X-ray diffraction preferred orientation data. Also, the uniformity as indicated by the experimental Sonic Orientation Resonance Tester was measurably less than for standard material.

The hydrogen content of the material, althayg specifled as 5 ppm or less, was anticipated to be falrly uniformly distributed over the specification range. However, actual analyses revealed the distribution to be as follows:

$\begin{array}{lr}\text { PPM } & \phi \\ I I & 0 \\ 1-1.9 & 4 \\ 2-2.9 & 21 \\ 3-3.9 & 50 \\ 4-4.9 & 17 \\ 5-5.9 & 4 \\ 6-6.5 & 4\end{array}$

Initial beta reheat treating tests with the dingot material was considerably more prone to warping than standard material. Heat treating tests conducted to date in the bigh alpha temperature range have not revealed the same proneness to warping as did the beta temperature range beat treating. Further heat treating tests are being run in addition to measurement of warp under actual canring conditions.

In view of the emphasis on dimensional stability of fuel cores and 1 to relationship to grain structure, the advisability of unqualified use of this material was questioned. The suppliers of the material were informed of our concern over its use and questioned as to possible causes for the observed variations. To permit complete review of our findings and discussion of possible corrective measures which could be taken to provide uniformity of product," a meeting was scheduled at HAPO with representatives of MCW and FMPC. Although the data prem sented and the discursions held did not permit positive identification of the influencing variables, it was agreed that determination of the effects of the heat treating variables possibly offered the most expeditious solution to the problem. Therefore, it was further agreed that each site would conduct studies of the heat treating variables and their influence on the stated problem. On

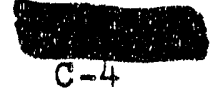




\section{DECLASIFIED}

April 1 a meeting will be held to coordinate the findings of the three sites. To determine interlm action, discussions will be held with IPD to determine a charging program for dingot material.

Sonotesting of the initial. lots of materlal chloride-blank heat treated with a 43 second transfer time indicates grain size control comparable to that experienced with carbonate-rod heat treating has been established. Further recelpts of this material will be necessary to determine the full range of variability in Sonotest rejection rates which can be expected under full production use of this material.

Study of the possible causes and means for correction of the large increase in rejection of recovered cores first experienced in October 1958 is being concentrated in the following areas:

1. What process changes may have been made at FMPC to influence such a change in rejection rates.

2. What influence did the change in lead bath conditions at HAPO have on the uncovering of striations in the cores.

3. What are the comparative strengths of cores with varying degrees of striations.

4. Are the present visual inspection standards reasonable and are they compatible with current fuel core quality requirements.

Process Technology

Horizontal preheat and agitation in the duplex bath appears to give the most uniform internal and external bonds yet produced. It is planned to use one duplex furmace in the 313 Building with a horizontal duplex basket and to compare pieces canned by tais method with regular production for several months.

Temperature profiles at canning jack positions in the canning furnace were different for each furnace tap setting and for six and eight-inch can-sleeve assemblies. This temperature profile appears to be a method of optimizing tap settings vs. can-sleeve size if profiles are made for each canning furnace.

Complete cap-spire wetting has been obtained by preheating uncleaned cap-spires in a molten alkaline hallde flux followed by a short dip in the canning bath. A larger flux fumace is needed, however, to further evaluate this method for eliminating cap-spire non-wetting.

Process Engineering has assumed the responsibility from HLO of fabricating seifsupported fuel elements for IP-84A in B reactor. This test requires four tubes of self-supported per month starting in mid-February. Two hundred self-supported down stream dumies were welded for this production test for ten additional tubes.

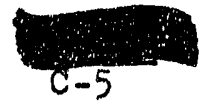


There have been no autoclave Iailures since spire etching was started on December 2, 1958. The average for the first eleven months of 1958 was two per month.

The first production man on the new 8 " " $K "$ slze fuel element was made during January.

The Inclusion reject rate has been below 1 per cent for the past three months. Because of this low reject rate, no further work in this field by Process Engineering is planned,

The water mixer welding equipment was moved from 306 to the Weld Lab. in 313 Building. Five or six thousand water mixer fuel elements are scheduled to be wellded before the end of the program in July.

The first three production radiograph model trays, fahricated off site, have been received. Before they can se installed for production use, however, they must be piped, wired and adjusted. Also, one radiograph machine must be converted to handle the new trays.

A prototype system utilizing carts and a mechanical dumper to collect the aluminum lathe turnings and dump them into the recovery furnace has been tested and approved. A study is under way to improve present handling methods for screp which is wet, dirty or oily.

In order to eliminate discrepancles which sometimes appear between pilot plant test results and 313 production experience, the canning equipment in 306 was re-arranged and equipped for 4-man line, to match the 313 lines.

\section{Pilot Plant Activities}

About 5240 uranium cores were canned in the Pilot Plant for nrocess development purposes and 120 I \& $\mathrm{E}$ aluminum dumies were dip cannea for off-site machining studies. In adition, about 2600 watermix spools were welded to six inch normal uranium I \& E fuel elements. The major items of process development were:

1. Component cleaning improvement tests to reduce the aluminum non-wet problem:

a. Etching caps and cans in caustic (Aluminux) with and without ultram sonics in the diversey 514 deoxidizer.

b. Amount of can wall etched off in Aluminux on ean wall wetting in Alsi.

2. A test to improve the bonding of six inch I \& E enriched cores by using a horizontal duplex basket.

3. Improved can preheating tests to reduce the bottom freeze out problem:

a. Using a 45 second cycle with 9 per cent silicon in the canning bath with two stationary baskets for additional can-sleeve preheating

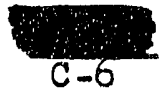




\section{DECLLSSFED}

HW -59107

positions which gives an 80 second preheat and a 35 second submerge and assembly time.

b. Using a single canning method which uses a stationary basket for obtaining 80 seconds preheat and 35 seconds submerge and assembly time.

4. Cans with various can base recess I.D.'s were canned to determine the effect of spire-to-can-recess annuli on intemal porosity and tube wrinkling.

5. Wetting tests on empty cans to:

a. Determine effect of nickel-aluminum alloy (x-8001) on wetting.

b. Determine method of measuring relative wettability of cleaned cans by varying preheat and submerge times, bath temperatures, and silicon content of Alsi.

6. Normal cenning of fuel elements for:

a. Control pieces for bumper fuel element production test in $K$ reactors.

b. Pilot mun of new size I \& E fuel elements (KIIIN).

c. Pilot run of large grained dingot OIIN to determine amount of porosity and warp.

\section{MATSRIAIS ENGINEFERING}

\section{Coextrusion of Uranium and Zircaloy -2}

\section{Off-Site Extrusions}

Extrusion Run \#I - (NPR-KER Rod) - The scheduled' starting date of 3-3-59 has been selected. Due to delays by uranium suppliers the schedule is tight. Assuming the use of overtime in 306 shops to do uranium machining, the date can be met. Sixteen billets is the target number. If additional billets can be made they will be used to produce .593 rod for use in development programs sponsored by Fuels Fabrication Developnent Operation.

Extrusion Run \#2 - (Small Tube) - A work order was issued to initiate fabrication by shops. The scheduled shop completion date is 3-15-59. The recommended extrusion target date is 4-22-59.

Extrusion Run \#3 - (NPR Outer Tube) - Billet design is complete. Recommend discussion with BBC by 2-25-59. Extrusion is scheduled for May, 1959.

Extrusion Run \#4 - (NPR Rod) - Design calculations to be complete by 2-15-59. During January, NMI had fair success extruding KER tubes using the integral die cone system on their press. Design of tooling for Run \#2 has been changed to use this tooling. Rod extmusions during Run \#4 will be set up to use this die design in direct comparison to the die-cone method.

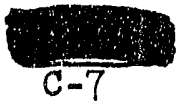




\section{DEDAREADD}

$H W-59107$

Zircaloy Cladding Materials - The first shipment of zircaloy-2 tubing for the small rod extmusion has been delivered and is being machined to billet component dimensions.

Copper Jacketing Materials - The copper jacketing components for off-site extrusion run \#l have been machined, and the assembly operations of cleaning, welding, and outgassing are now in progress.

Post Extrusion Examination - A report outlining the quality testing of the rod product from the first off-site coextrusion (l'arch) has been prepared. The tests will be performed on the product in the us-coextruded, as-swage as-beta heat treated, and alpha-canealed conditions. The report points out that the most difficult problem to jvercome is that of betameat treat. and maintaining straightness. By analogous experience with Category I fuel. elements, the control of warp during the quenching operation must be achieved.

Cold Coextmusion - A series of ten zircaloy-2 clad uranium billets were cold extmuded at Hunter Douglas Division of Bridgeport Brass Company to hollow clad tubes and returned to HAPO for evaluation. Of these ten, six were welded mechanical assemblies and four were fabricated by vacuum casting a uranium core into preformed zircaloy-2 components.

As the cold extrusion process does not readily promote bonding the cladding to the core, a technique for fabricating extmusion billets initially bonded would be extremely useful. To exploit this possibility, HIO was requested to prepare several billets using vacuum casting techniques to produce a bonded assembly. Four billets were fabricated in this way and sealed by an electron beam welding process. The other six billets were simple welded mechanical assemblies.

Cursory examination showed one electron keam weld on a cast billet had parted slightly. This particular weld was the one experiencing maximum tension. Sectioning revealed the outer zircaloy-2-uranium interfaces were virtually unbonded; hover, it is very doubtful if they were bonded during casting. The extrus: on does not appear to have broken mary, if any, bonded areas. The inner ube appeared bonded. HLO f'eels that with a little more development, a reliable bond casting technique car be perfected.

The mechanical assemblies all appeared sound but with a somewhat wrinkled inner clad. Sectioning revealed an annular break in the inner clad at the rear terminus of the core - most were muptured completely around, learring a definite gap in the inner tube. The cause for these failures is under investigation.

Surface condition was variable, ranging from fair to poor - the worst occurring on the cast billets. Hunter Douglas reports surfaces could be improved by altering extrusion conditions.

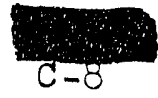


Extrision - Pijot Plant

Chemican Processing

\section{Surtace Preparation - CIeaning}

Chemical - Desien criteria for all phases of chemical surface cleaning and preparation have been autmitted to Design \& Projects noeration for coextmsion pilot plant facilities. These criteria were based on all aveilable data on-site and off-site and 1acluded the recent report of HWO 3 IF etcin specifications by the Coktings and Corrosion Operation, HIO. Design criteria wez"e isbuea, under separate cover, for the copper rewoval Iacility. These criteria were based on copper removel from the extum sion in rod form. Eanding equipment was also specified.

Mechenical - Specifications fur the vapon bone machine have been rem viewed and coments submitted to Design \& Projects. A letter who Written regerding alternate processes to vapor honina vi fuel segments to remove heat treat scaie ard oxlaes. The alterates proposed were: 1) Bmaking, grinding, and polishing, 2) copper removal after beat treating. Investigation in these areas is presentiy being maje. It wes recommenced to Desin \& Projacts operation that procurement of the vapor hone equipment be delayed as long as possible in oroder to evaluate these theruates.

\section{Rexovery}

A.s a resujt of recent commaleation between FPD and HLO on chemical rpiearcin sna development supportine coextrus ion recovery processes, a profran hes beer forminted and agreed upon by the parties involved.

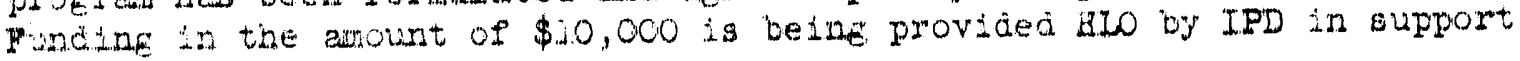

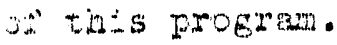

\section{Equatereat}

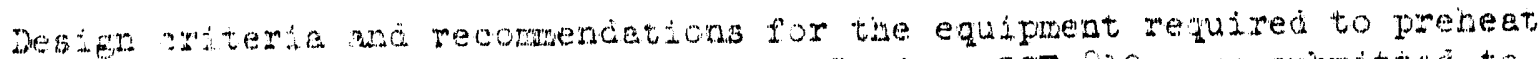

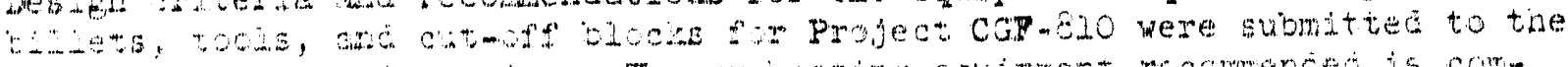

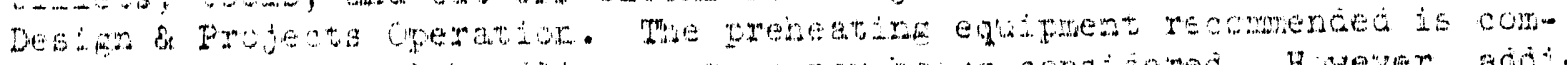

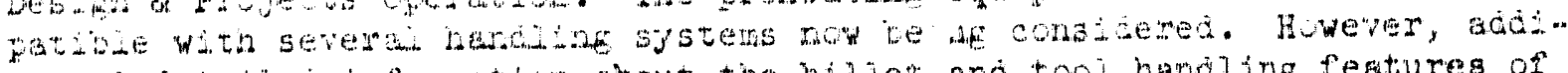

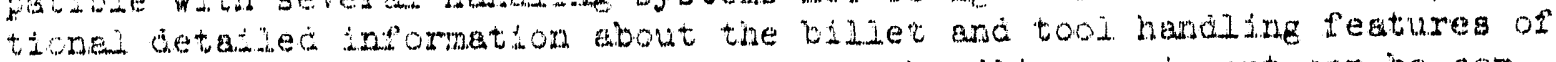

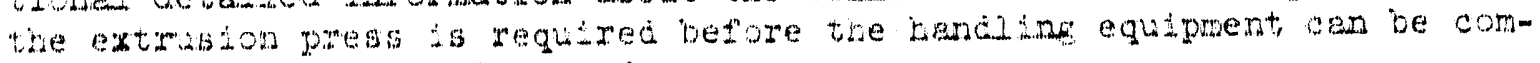

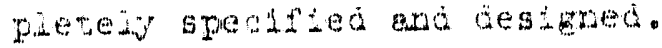

\section{KER Test Lacp Pue: Elewents}

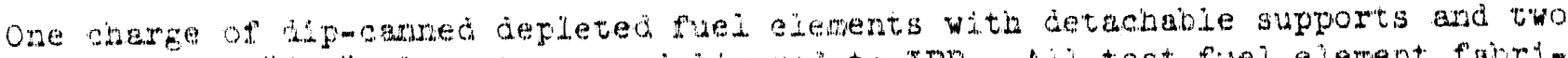

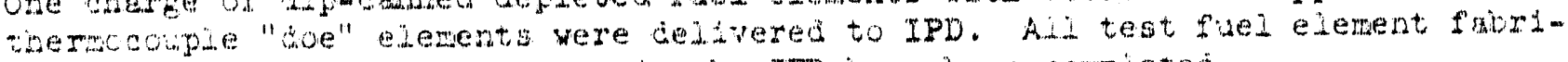

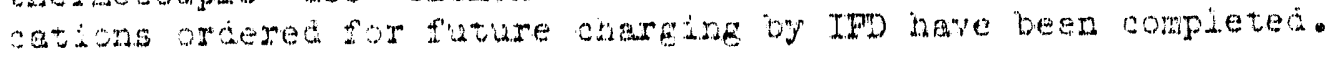

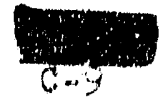




\section{Aluminum Cast Blanks}

Sample cast blanks tipical of" those to be used in producing 10,000 sets of " $\mathrm{C}$ " size X-8001 I \& $E$ componente have arrived. Cursory examination shows then to be of acceptable quality; however, further analytical work is under way. Scheduled delivery for the 10,000 component sets is 3-1-59.

\section{TESTING METHODS}

Process Fuel Element Testing

Internal Penetration Test

Additional experiments with the Bump Discriminator were made with $\mathrm{K}$ sizt: I \& E elements. Some reduction in false reject rates is obtained by using the ilump Discriminator probes and these will be continued 1 in lase on all process testers. Retestinf; tise "rejects" with the Bump Discriminator electronics also effects a reasonable separation of those refectec because of teater sensitivity to surface irregurarities. However, even when using the complete Bump Diacriminator, the test cannot be run at $0.020 "$ sensitivity without unduly high reject rates due to iaxge surface bumps and braze layer voids. Therefore, recomendations were made tisat the Intemal. Pen test be continued on all production at the $0.012^{\prime \prime}$ thin wail sensitivity level. Gross defects are thus placed in the "reject" category shich is staistically sampled by destructive caustic peretration for assurance (at a high confldence level) that the internal clading thickness exceeds $0.020^{\prime \prime}$. This favors the detection of true thin walls by the statisticil test, but does not provide 100 per cent protection against the releuse of one.

One bundred per cent protection against the release of internal tinin wallo Less than $0.012^{\prime \prime}$ can be obtalned for the cost of reteating the "rejects" with the $B D$ and classifying the rejects from this test as true rejects. This is being considered.

Development effort are being concentratied on attempts to improve the kesic stenal-tomnotse ratio of the intemal pen tester so that it can be usec on production at nearer the goul $0.020^{\prime \prime}$ level. It this can be achieved, it way be achantagecus to use the Burp Discrininator circuts also on a 100 per cent basis.

Extermal Penetration Cest

Purther comparisons of the probe-servo and tape-head sensing systems continued to show that the tape system has an advinterse in lower reject rates ( $1.9 \%$ vs. 2.5 for approxinateiy 45,000 ejements tested on each). This dis due to less sensitivity to surface defects and higher siguaj-tonoise ratio. The tape syster has been very rellable except for tape treakage. A new type Rujor tape has been ordered to repiace the present Teflon tape wh dielivery expected in early Pebruary. If the Rulon tape is as superior as the specifications predict, the new type tapeninead system wil have a clear-cut ksvartage for fill production use.

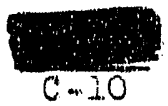


Internal Bond Test

Work is in progress towards applyine more restrictive standards. Comparison test on $K-8$ material usine a $0.5 \mathrm{~cm}$ standard and the reguiar $0.75 \mathrm{~cm}$ stancturd gave inconclusive results. Preparation of $0.5 \mathrm{~cm}$ standards for other size productis is under way.

External Bond Test

Several hours of tester aowntime were causeä by faulty tranducers. This has been corrected by converting to Curtiss-wright crystals pending the delivery of' IIthium-suiphate crybtals which were crdered for evaluation.

Modiflcations to the amplifier clrcults aimed at removing some of the bandwidth limitationa are being studied.

\section{Transformation Test}

Instailation of the new flued crystal mounts on the 313 teaters has been delayed due to maintenance problems. The 12 "standards" fabrlcated by alo to bave small. untransformed areas were not satisfactory. They either bad no untransformed regions or untransformed areas many tines the desired size. Purther work is being aome by HLo to control the heat treatment in auch a way as to produce the needed "standards".

A barium-titanate crystal installed on the 306 tester in 6-58 operated with no meintenance until 1-30-59 when it developed a loose ground wire. This is a wuch better performance record than that obtained with the quartz crystas used in the 313 builatng. Barium titanate is used on the new Bare Core Teat being ceveloped for 313 .

\section{P1 lot Plant Bonc-Penetration Tester}

The new electronic console ( 323 model) was chelvered $1-30-59$ and should be instalided durine early pebruary.

MPR anc Catecory II Development

Preiminary laboratory experiments indicate that internal defects in uraium ingots for coextrusion of INPR type fuel are detectable with an ultrasonic test operating at a frequency of one zyegaycle per second.

Zircaioy clacidng antegrity testing by eddy current methods at 250 kc detects air fli2ec notches which come within $0.010^{\prime \prime}$ of the sliaface of o. $0.020^{\prime \prime}$ thicis claciding. Further tests will be macie at higher frequencies where increased sensitivity is expected. U2trasonte methods have also been successful in detecting the same defects, but beparation of the desired signal from surface noide appears nore difficult.

Seventen $0.5^{\prime \prime}$ diameter coextruded rodis were bondested. No unbonds were detected.

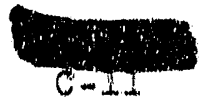


New Methods Development

Cap Core Bondtest

Adalional studies were completed on the development of an u.ltrasonic capcore bond test. Angled bean techniques using the refraction of both longitudinel and shear waves failed to give a practical means for bondm testing the central regions of the cap-core annulus. The direct beam test or the cap area beneath the weld gave further successful results despite inregularities in the surface of the weld bead. Five of 100 elements tested bad detectable unbonds. These were not visible after breaking the cap, but the unbond signals were so strong that it is believed a Iractured bond exiated. It is of interest that four of the five indfated unbonds under the weld bead overlap, suggesting that the bond may have fractured as a result of thermal shock during welding. Equipment is being ascembled to set up a capmcore bondtest in the 313 buliding. This will be used to evaluate the method for Quality Control or process use and as a tool to aid current process improvement studies.

Sonic Orfentation Resonance Pest

Pive hundred gamna extruded dingot uranium cores were tested. These showed more than usual varlations in frequency readings. Three cores which had. very low torsional resonant frequencies were found to have an intermal crack the full length of the core.

Wive cores with a range of frequency readings were shipped to $P$. M. Morris of the Natiunal Lad Company. He will examine them for stringer concentra. tion, chemical composition, fabrication blstory and graln orfentation by $x$-ray diffraction.

Several improvements were made to the prototype sorT equipment.

Bare Core Test

Uitrabonic attenuation tests vere made on samples of gamne extmaded dingot metal to obtain quantitative measurements of minimum and average grain size. oscilloerans were aiso taken with an image storage oscllloscope (Hughes Memoscope) to show the variations in grain size within a fiven core. These Cata gave $\varepsilon$ good demonstration of the potential usefulness of thia test for establishing an upper limit or grain size and grain size nonualformities, ard for quantitatively categorizing grain size quality.

If present olrcult development woris continues to give successful results, both the atteruation test and surface test functions of the Bare core Tester will be fully transistorized. Satibfactory pulser, receiver, and gating cliscuits have been developea. Some further improvement is needed in the alarn circults. The clrcult designs are being planned to permit fabrication as piug-in circuit boaris to simplify maintenance. Wherever possible, comparable clrcuit functions for the attenuation and surface testers have been designed to uge the same circuit bourd construction with but minor changes in component values. It is hopect that this can leas to economical fabrication by a compercial firm.

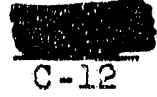


The prototype test tank and conveyor has been delivered to the laboratory. Installations of electrical and plumbing services, photocell controls, and transducer mounting for the attenuation test have been completed. The major current problem with the unit is the elimination of air bubbles in the water. Use of stear condensate is being investigated as a possible solution.

Planning for the data recording system continued. At least one vendor bas been found who can supply a translator unit which can convert tbe readout signals from the test channels into jnputs for a comercial paper tape puncher. The system will log in digital form the test parameters for each core tested. IBM computers can be used to process the tape and obtain frequency distributions, means, and standard deviations for each "lot" of tested material. Another machine can be provided to read the punched tape and transcribe the logged data into a printed record for imnediate manual analysis by Engineering or Quality control. This type or serial system is much less expensive than a parallel system having simultaneous data logging with punched tape and digital printing, because it can use a low-speed lowcost printer.

\section{Aluminum Can Test}

Earlier work with the prototype equipment showed that it is necessary to clean the cans before testing to avold excessive false rejects from dirt build-up on the probe. Another 1600 cans were cleaned and tested with a final reject rate of $7.5 \%$. These rejects are being sectioned to look for seams. A total of 13,000 cans have now been tested and oni seam has been found. The tester has not passed any seams that have been detected after etching. Consideration is now being given to the economics of continuing the test on the remaining 110,000 suspect cans, in light of the added cost of cleaning, the demand for $8 "$ solids, and the evident low incidence of seams.

Residual Can Wall Tester

Work continued on the yrogram to develop an instrument for measuring the absolute can wall thickness of Alsi canned fuel elements. This is intended for use by Quaity Control as a nondestructive supplement, and possible eventual replacernent, for the destructive caustic penetration test. The developmental approach being investigated uses the edid current method in an absolute sense rather than in the differential sense as used in the process penetration testers. This requires especially stable and low noise signal generators, balance clrcuits, and amplifiers. Detalled analyses are also beine made of the effects of' coil design and the effects of unbonded areas beneath the cladolng.

\section{Henford Test Reactor}

Metal testing continued routinely. Several special tests were concucted including aditional graphite heasurements for the Babcock and Wilcox Co. The "Ip" size graphite standaros were recalibrated and rechecked against each other to obtain

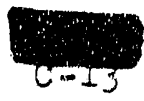


new factors which will normalize graphite test results to the old 35 standards. The "F" size graphite purity coefficient was also remeasured. Small changes over previous values were obtained as a result of the new control rod calibration and density inhour coefficient. All graphite test resul.ts siuce 1953 can be converted to the inhour values that would be reasured now. Tests prior to 1953 carnot be converted because of uncertainties in the density corrections.

The test reactor manual, including the latest graphite test data, is being typed in final rough draft form. It should be published in about a month.

\section{Customer Work}

105-C Basin Bondtest

Assistance was provided for adjustments and maintenance. Two new Model $1 B$ Bondtesters ( 313 model) are being fabricated to replace the existing equipment which was assembled from early Testing Method's prototypes.

\section{HLO Bondtester}

A Bondtester is being set up for E. A. Smith of the Fuels Fabrication Development operation using one of the old Bondtester units removed from the 313 building.

Plutonium Tensile Specimen Tests

The HIO Plutonium Metailurgy Research Operation has requested assistance in the development of nondestructive metinods for testing Pu specimens fic porosity and small intemal cracks. Initial investigations are simed at deternining the feasibility of ultrasonic transmission tests on these size specimens and for these type def'ects. Later it may be advisable to consider eddy current and sonic vibration methods also. In all cases, some new experimental problems are imposed by the requirements for remote operation. It is expected that the initial studies can be done by adapting existing laboratory equipment and with about $4-6$ man weeks of engineering assistance from Testing Methods.

\section{HIO Resin LeveI Detector}

At the request of $\mathrm{C}$. L. Pleasance of the HLO Cherical Development Operation, a prototype instrunent was developed for measuring the level of a resin interface in a CPD liquid column. This instmunent measures the transit time of uitrasonic enerey from a fixed transducer at the top of the column, to the resin, and back. The ultrasonic frequency is selected to optimize reflection from the resin interface. Special circuits were devised to obtain a signal proportional to the resin level. Favorable results have been obtained by Pleasance in testing the equipnent in a ten foot colunn under simulated operatine conditions.

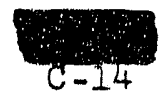




\section{Ultrasonic Vibration}

Assistance is being given the HIO Corrosion and Coatings operation in their programs related to ultrasonic vibration of liquid aluminum melts.

\section{Washington Designated Nondestructive Testing Program}

Ultrasonic Lamb Wave Studies

Attention has been given to the development of analytical equations for calculating the component particle displacement (in a thin plate) as a function of particle position, and for the various vibrational modes which have been experimentally observed in thin plates. It is hoped that this analysis will yield an explanation for the observed anomelous behaviours, but the results so far have not been successful.

\section{Broadband Electromagnetic Testing Studies}

Calculations of the response of the equivalent circuit representing an electromagnetic test were made for $5 \mathrm{kc}$ sinusoidal, step function, and impulse function driving functions. The impedance of the approximate equivalent network. for the $5 \mathrm{kc}$ sinusoidal driving function was calculated for a range of resistance values from zero ohms to open-circuit for two cases. The first case represented a thin inetal of various conductivities and the second a thicker metal. The time comain responses of the network to step and impulse function inputs were calculated for $R=10$ and $R=20$ ohms. These showed that the impuise response is proportional to the square of the network resistance (metal resistivity) whereas the step function response is directly proportional to the resistance. Measurements confirm this result. This may have useful applications and its significance will be further examined.

A physical equivalent circuit was completed and meesurements of its response were made using a $5 \mathrm{kc}$ phasorscope (Vectorscope). Reasonable agreement with the calculated values was obtained.

Arrangements were made with HLO to have additional network response information calculated on the analogue computer.

A draft of the first report on this phase of the prcaram was written, including data on calculated and measured response of the equivalent circuit. The response of actual test probes of the probe type and encircling cylindrical type are also shown for various metals for comparison with that of the approximate equivalent circuit.

Work has been started on the second phase of this study to determine whether or not the speciflc variations of the values of the net work shunt resistances can be determined from the observed changes in the input impedance of the network. This will be a combined analytical and experimental approach as a direct analytical attack presents great aifficulties. It is this phase of the work which is expected to show the practicality of the broadband approach in securing more information from a test than is available from the single Prequency method.

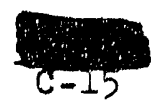


Assuming that this study will progress as anticipated, a favorable demonstration of the broadband approach may lead to application on the internal penetration test for I \& $\mathrm{E}$ elements. The presence of acceptable structural varlations in the fuel element causes signals which exceed the reject setting resulting in false rejects. The Bump Discriminator operating at $1 \mathrm{mc}$ has helped this situation, but further gains are belleved possible by use of an integrated instrument using a broadband or multiple frequency method.

\section{DESIGN \& PROJECTS}

CG-713 - Conversion to I \& E Lead-Dip Fuel Elements

The welder-buffer system is in operation, but is being utilized only intermittently while minor bugs are worked out. Most clean-up work has been completed and the project as a whole is more than serving its intended purpose.

\section{CG-759 - Additional Steam Generating Facilities}

The boller is producing stearn, and actual firing operations are under way. The bullaing is now completely enclosed.

Arrangements were made with the Chemical Processing Department to provide an operator experienced with this type of boiler to instruct our personnel in the operational characteristics of the new boiler and related equipinent.

\section{CA-774 - 300 Area Water System Modifications}

Contract work is complete except for restoration and testing. Hydrant work by Minor Construction forces is being held up pending favorable weather conditions.

The 225,000 gallon reservolr failed on January 11, 1959. There is evidence which indicates leakage in the area of the sump caused the fallure, but the evidence is not conclusive, and there is no way of determining positively what started the leak. Methods of repairing the tank are being investigated.

Basically, the repairs will consist of pressure grouting to stabilize the subgrade, and positive sealing of the cracks. The contractor has contacted a specialist in the grouting field for a proposal on this phase of the work.

\section{CG-787 - Sprinkler System - 313 Building}

Installation of the sprinkler system was completed on January 14 . Inspection by a representative of the Washington Rating Bureau is scheduled for February 10, 1959.

\section{CAF-792 - Warehouse SpBce - Manufacturing}

Work by the contractor is complete except for asphalt installation which has been beld up by unfavorable weather.

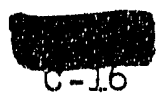


Arrangements are being made to move the sprinkler pipe which extends across the doorways out of the area of the doorway. Inspection of the sprinkler system by the Washington Rating Bureau representative is scheduled for February 10, 1959.

CG-810 - Pilot Plant Expansion

The helium leak detector has been set up and checked out. The welder for copper assembly has also been set up and some copper welding has been done. Relocation of equipment and duct work is under way.

Arrangements have been made with the Hanford Laboratories Operation to request completion of the press area in time to install the press.

All quotations on the extrusion press were rejected, and a new request for quotations was issued. New quotes were received on January 21. These quotes were evaluated and recomendations forwarded to Purchasing. The package is currently awaiting approval by the $A B C$.

CGP-820 - Revision I. Warehouse Space - Engineering

Authorization to proceed with the design has been received.

DRAPIING \& FILES

Major Jobs in Drafting

306 Building:

Electron Beam Weldex

CGP-810 - Billet Assembly and various details

CGI-8.10 - Billet Etch Basket

313 Bullding:

Automatic I \& E Stamper

Quality Control Reporting System - Console Board

Duplex Loader Connections

Neutral Salts Crucible

Misc. equipment as-builts

Misc. building layout as -builts

Tape Head

Miscelizaneous:

300 Area Maps - Steam, Sewers, Air as-builts 3723 Pire Alarm

Drawligs Produced:

$\begin{array}{lr}\text { New } & 51 \\ \text { Revised } & 69 \\ \text { Large Charts } & 0 \\ \text { Small Charts } & 44 \\ \text { Miscellaneous } & 59\end{array}$

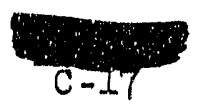




\section{DECLASSFIED}

HW-59107

\section{ADVANCED ENGINEERING}

Paim Olive Program

A proposal that the Puels Preparation Department construct a production facility for fabricating and canning palm target elements was prepared. The building would consist of approximately $4500 \mathrm{ft}^{2}$ and the high spot estimate total is $\$ 1,500,000$.

Hanford Production Capability Study

The original study was reviewed to determine what changes would occur if the second NPR was in operation by 1963 and required aluminum clad fuel elements. Results were that capital requirement for production facilities in FPD would be needed in 1.961 instead of 1964 for the second NPR and operating costs remained the same as in previous studies on aluminum clad NPR fuel elements.

Casting Aluminum Jackets on Uranium Cores

A review is under way of casting aluminum jackets directlj on uranium cores. If such a process is feasible and can be developed, it showld result in substantial savings in component costs.

Nickel Plating of Fuel Elements

Efforts were conflned largely to preparation, examination, and selection of the four charges (two chemical-plate and two electro-plate) for the in-reactor Production Test IP-207-A-3-FP. The chemical-plate was more consistent in quality, and superior to the electroplate with respect to continuity, uniformity of thickness, and adherence. However, the quality of the electroplate can be considerably improved with further development of equipment and procedures; likewise, the chemical plate exhibited discontinuities and thickness variations due to equipment and process deficiencies which can be readily rectifled.

The platirif on the elements selected for reactor charging wil. not give maximum corrosion protection, since some discontinulties are present. However, these elements should satisfactorily fulfill the primary objective of the test which is to provide data on reactor effluent contamination; in addition, some useful corrosion information will be obtained. The possible phenomena of accelerated aluminim corrosion at the site of discontinuities in the nickel plate, has thus far not been observed on electroplated fuel elements tested in reactor water, both in ex-reactor flow tubes and by irradiation to high-goal exposure. Thus the risk of a fuel element rupture due to discontinuities in the plating appears small. Further information will be provided shortly by ex-reactor corrosion tests which are being carried out at present by the HIO Coolant Systems Development Operation. These include flow tube tests in $50 \mathrm{C}$ and $120 \mathrm{C}$ reactor coolant, and $300 \mathrm{C}$ deionized water.

The six charges (including two controls) of PT fuel elements were shipped to 105 wC for charging in an outage in early Pebruary. However, tubes had not been made available, and thus charging will be delayed until mid or latter february.

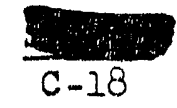




\section{DEPIASSIFED}

Preliminary tests for porosity were carried out comparing 0.5 mil thick and 0.2 mil thick chemical plate, using C.64 alloy cans plated by Kanigen. Results were encouraging in that while the $0.2 \mathrm{mil}$ thick plate was porous, the porous area was confined to about $1 / 2$ to $2 / 3$ of the can surface, and the remainder was pore-free. These results suggest that handling and cleaning procedures and/or equipment might have caused the localized porosity, and that a pore-free 0.2 mil thick plate might be produced with feasible process improvements and controls. Further testing of nominal $0.2 \mathrm{mil}$ thick and preliminary testing of $0.05 \mathrm{mil}$ thick plate will be carried out shortly.

\section{INVENTIONS}

All Engineering Operation personnel engaged in work that might reasonably be expected to $x$ wut in inventions or discoverles advise that to the best of their knowledge and telief no inventions or discoveries were made in the course of their work duing January, 1959 except as listed below. Such persons further advise that for the period therein covered by this report, notebook records, if any, in the course of their work have been examined for possible inventions or discoveries.

\section{NONE}

JW Talbott:ribs

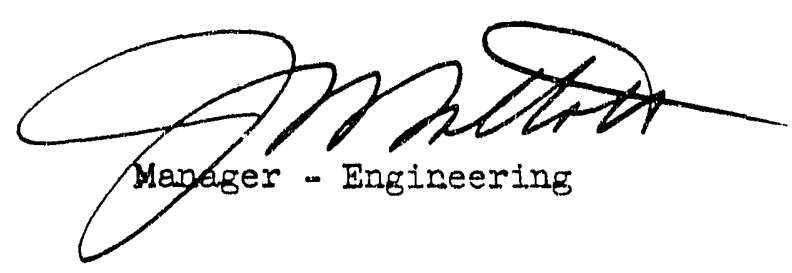


FINANCIAI OPERATION

JANUARY, 1959

\section{AUDITS AND PROCEDURES}

Auditing - Internal auditing activities during the month largely consisted of investigation of or consultation on the following subjects:

1. Unfform reporting of suggestion plan statistics

2. Changes on One Trip Material Pass Control procedures

3. Conducting of government property se iches to reduce misappropriations

4. Appropriateness of FPD property management practices

5. Implementation of protective clothing control procedures

6. Maintenance of insurance claim processing and status records

Office Procedures - A detalled study was made of present employee records maintained by Personnel Accounting, Salary and Wage Adninistration and Personnel Practices. In support of the uniform goal to consolidate these and eventually other personnel records in the Department, recomnendations were prepared and agreements largely completed as to the fliling system, procedures for combining records, and retention or disposition of specific documents.

Considerable time was devoted to activities of the Integrated Procedure Council. This work included a report on the first four month's accomplishments of the Council, study and investigation of several new projects, follow-up on status of a number of earlier projects, and dissemination of source information applicable to current studies by the Council members.

A number of electronic data processing considerations were reviewed and appropriate replies or proposals made. These subjects included suggested major revisions of the Personnel Source File, changes in payroll check format and preparation, proportionate amount of service work performed for FPD, improvement of the accounting coding structure, and orlentation on the features of the IBM 709 Computer.

Other significant procedures work involved participation in the FPD Work Simplification Course and processing of a number of new and revised forms, most of which were further modified and improved.

\section{GENERAI ACCOUNTING OPERATIION}

Under the new "bookless bookkeeping" method of accounting for cash advances, total time spent processing travel data is approxinately $25 \%$ less than under the old method. Time previously required for ledger posting is being effectively utilized in connection with the development of the integrated ledger system.

The Department Reduction of Force Policy was rewritten to include a dis lacement procedure for exempt employees. The new policy sets forth principal criteria to be used in evaluating excess exempt employees to identify possible displacement candidates. 
GENERAL ACCOUNTING OPERATION (continued)

The Travel, Living and Moving Expenses Guide was revised to incorporate several changes. A paragraph was added to provide for the General Manager's approval on travel East and/or return via Seattle or Portland when fare via these points is more expensive than direct routing. A section was changed to state that Federal Income Tax will no longer be withheld frum allowances and relmbursement to newly hired employees for expenses incurred in relocating their family and/or personnel effects. The guide points out, however, that employees are still responsible for reporting payments as income on their individual tax return. The new convenience provided by General Accounting Operation for one-stop service in the 300 Area for picking up cash, checks, and tickets was also incorporated.

Comments regarding suggested changes in HAPO OPGs were submitted to Contract Accounting. Suggested changes included: (I) More specific identification of purpose as to Instruction, Policy, Announcement, or Organization; (2) that a HAPO guide regarding political activities be published to facilitate consistent HAPO-wide practice in this respect; and (3) changes in nomenclature, additions, and deletions to Appendix A of HAPO OPG 8.1 Assignment of Property.

In regard to the integrated ledger system, preliminary design is complete on all general ledger accounts except Inventories and Operating Cost. The over-all plan has been reviewed with Data Processing and found to be both feasible and proper. Procedure outlines are now belng drafted on each account to provide instmuctions for Programing. Data Processing Representative has stated that by February 16 a Programmer will be available to start actual programming. The goal at this time is to have all General Accounting Operations accounts ready at that time and to followup as rapidly as possible with Operation Cost. Inventories wlll be considered as time permits.

Property Management Operation, Relations and Utilities Operation informally approved proposed catalog descriptions covering Buildings and Building Service Systems. Changes will be i,icorporated into the installed property catalog and submitted to HOO-AEC for formal approval during February.

Samples of identification tags for installed equipment are currently being appraised. So far, the most desirable is a flexible aluminum tag which can be affixed to equipment through use of a plastic cement. The Manufacturing Maintenance Operation is currently conduating a final review of the proposed equipment numbering system.

A review of plant and equipment composite depreciation rates was completed during the month. Except for a few minor changes, rates currently in use are adequate. Changes will be reflected in accurals for the last six months of FY 1959.

Semi-annual listings of uninstalled equipment are currently being distributed to FPD property custodians to insure that charges to custodians by Plant and Property Accounting are correct. Listings can be verified with custodian's property control cards and physical inventory will not be required. Periodic checks will assist in the continuing accuracy of uninstalled equipment records. 
GENERAL ACCOUNTING OPERATION (continued)

The following equipment budgets for FY 1960 and FY 1961 were compiled and submitted to Contract Accounting in January.

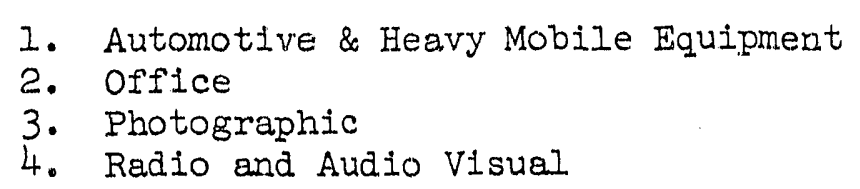

A total of 35 days were spent in travel status during January. A comparison of travel expense reported amounted to $\$ 7,729$.

MEASUREMENTS

The study of the Maintenance and Power bustness data booklet was completed. Results indicate the booklet can be a useful management tool.

Data and charts covering IPD activities were developed f'or the General Manager for his use during the February visit of GE Vice Presidents LaPierre and Fink.

The Department Measurement Report was brought up to date by substituting actual CY 1958 performance data for the 10 months actual and two months estimate originally used.

New Department performance charts covering CY 1959 have been prepared.

In future measurements and analyses of fuel element production, quantities wijl be entirely on a plece basis rather than a welght basis.

PERSONNEL ACCOUNTING OPERATION

In accordance with previous arrangements, Relations and Utilities Operation assumed responsibility for certain clerical and mechanical Personnel Accounting functions for FPD. One month's experience indicates these arrangements will prove to be satisfactory

Except for Employee Pension Contribution Record Cards, all year-end Benefit Plans reports and tax returns have been submitted. All deductions from employees' pay accounts have been balanced. Employee Pension Contribution Reccrd Cards were delayed pending receipt of additional information from Company and Enployee Trusts Acsounting.

The December, 1958 Consumer Price Index published on January 23, 1959 by the U. S. Bureau of Labor Statistics reported at 123.7, is the same as the Index for June and September, 1958; therefore, no change was made in the cost-of-living allowance to nonexempt employees. This is the second consecutive calendar quarter since March, 1956 that nonexempt salaries were not increased by a raise in the Index.

Plans are being formulated for physically combining records of Personnel Accounting, Salary and Wage Administration, and Personnel Practices. 


\section{PRODUCT COST OPERATION (contiuned)}

Meetings continued throughout the month to discuss detalled mechanics of Responsibility Reporting and Fixed Price Work Order procedures with all levels of management.

Fiscal year-to-date costs and the M1dyear Budget were recast through December 29, 1958, the effective date of the new procedure.

A meeting was held with Power Operations to discuss steam cost distribution. In the past, steam metered to the 313 Bullding was distributed to the Landiord account on the basis of degree days and remaining costs were considered process steam. Consequently, fluctuations in process steam costs have resulted. It has been resolved that a standard amount should be charged to process steam on the basis of production side the balance charged to the landlord account.

At the request of the Manager-Manufacturing Operation, FY 1959 budget estinates were Ieviewed and considerstion given to data not available during the Midyear Budget Review. Indications are that Manufacturing Optration costs for the year may overrun the budget by $\$ 32,000$ or $\frac{1}{2} \%$, and product1on costs (2000 Program - Preparat1on of Fuel Elements) may overrun by $\$ 43,000$ or $\frac{1}{2} \%$. The increases in fund requirements are attributed to: (1) aditional salary and related costs due to personnel increases and adine employees ln advance of budgeted dates; (2) increased consumption of steel sleeves; (3) product evaluation programs; and (4) changes in product mix.

A budget instruction letter to ald level 3 managers was issued January 12, 1959. In structions covered detall 1nformation required by Flnancial and established due dates $r^{*}$ equired to meet complonts to contract Accounting. Forms for personnel requirement.s and cvertine hours estinates were distributed on January 14 , 1959. Forms distriblitsd on January 23, to be used for other costs forecasts included actual cost fir the first s1x months of FY 1959 for each item required. We anticipate no delay in neeting due date conmitments.

A stidy was prepared to sumarize results of the Deparment's CY 1958 cost reducticn activitles by level. 3 operation. Total savings aegregated approximately $\$ 941,000$. In CX 1959 reports will be 1ssued quarterly comparing actuel cost reductions with C. 1959 geals.

Proustrity reworts for the fourth quarter and Cy 7959 were completed and 1ssuce i.e lest ween of January.

Comparison of CY 1958 results with CY 1957 and CY 2958 gCals reveals productivity Gatns of $37 \%$ and $9 \%$, respectively. Principal factors enntributing to productivity eains were yieli improvanents for all products and cost reduction programs condusted duriag Cr 1958.

Estingted requlrementis were made for selected ard controlled materials opveriak the second, tinird, and fourth quarters of' 1959 and the flrst guarter of 1960. Matertal: lucluded were chemicals, gases, and metals, 1.e., bianuth, alckel, steel, copper, aluninum and niciel alloys. 
PRODUCT COST OFERAIION (contInued)

The Department's Process Material unft price Ifquidation schedule for the third quarter FY 1959 was computed and distributed.

A number of montbs supply on hand as presented on the Process Material Inventory Report will be computed on the basis of Production. Document HW-58957 until further notice.

Current essential material transactions included a charge to the reserve account for first cost less salvage value of 172,000 R-I Aluminum Cans considered obsolete. Balance of reserve account after charge - $\$ 83,597$.

Current trangactions in Speclal Materials included a charge to cost for $168.9 \#$ of Zirconiun $(\$ 1,373)$ in connection w1th PR fiel element stuales.

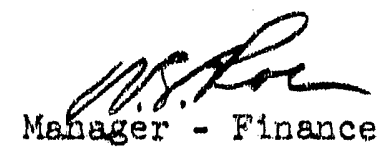

WS Roe:mh 
JANTJARY 1959

\section{GENERAL}

There was one Cost Reduct1on completed, representing an annul saving of $\$ 9,210$. This is 12 per cent of the Annual Budget.

Periodic Information Meetings Wth nonexempt employees were lnitiated. These meetings are held by the Ievel 3 Manager. The purpose of these meetings is to improve the two-way comunication between mangement and employees.

All office fling cablnets in the Department were anchored. This is the result of a recent safety survey urging that this be done.

ARES MAINTTEMTAIYCE

Duplicat1ng

Process

Multilith

Verifax

Ozalld
No. of

Inpressions

$$
\begin{array}{r}
528,161 \\
3,500 \\
1,112
\end{array}
$$

The Addressograph machine and Graphotype were 1natalled in the ma1I room. The Addressograph plates for exempt employees' plant addresses were moved to the 300 Area. Addressographing of plant mail. Is now being done by the Dupileating and Mall facility. This wark 18 being performed wth no additional manpower.

\section{General Malntenance}

One hundred and sixty 200-bole fuel element pailets were reconditloned and converted for use in poison element pallets.

Four alr conditioning outlets were installed over the cap and can machine in the 313 Eutlding.

A burst test shelter shed wes installed on the west wall of the 314 Euidajng. This shed will house two burst test units for use in research programs.

Several. tipes of sodium "bombs" were bullt for experimental purposes. The be units are being 1nstalled in a remote location across the highway from the 300 Area. These bombs are being used to deternine the inherent dangers in the use of sodium in the various processes.

A stainless steel. exhaust box, $36^{\prime \prime} \times 22^{\prime}$, was fabricated por use in f1Iling aluminum tubes with uranium powder". The use of this box prevents the excesalve spread of uranius contamination. 
The second high pressure loop for KER was completed. The fabrication of the loop and instaljation of punps in the loop was accomplished in the 326 Maintenance Shop. The electric control panel was fabrlcated by Instrument \& Electrical Malntenance Operat1on.

\section{INSTTRUMENT \& ELECTRICAL MAINTIENANCE}

The Portable shop repaired a total of 1,021 radiation detection instruments. The average time per instrument was 1.06 manhours.

Water meters in the RIchland distribution system were converted from U.S. gallons to cubic feet.

The high temperature alarm was destaned and Installed in the Thermal Test Reactcr in the 305-B Bulla1ng. This devi:e will alert operating personnel in the event that effluent cooling water reaches $50^{\circ} \mathrm{C}$.

Two manometers were installed in the FRTR test loop in the 314 Bullaing to measure the amount of leakage from the fuel element tube.

A Republic differential pressure transmitter was modifled as a remote welght transmitter for use in the 321 Bullding. This device was calibrated to read. from zero to 12 lbs. It $1 \mathrm{~s}$ being used to determine the dissolving rate of fuel elements in the Niflex process.

The garma ray fhotometer was assembled for use by the Ceramle Fuels Operation, 325 Buflding. It 1s being used to messure the density of ceramic fuel elements. Cobalt $601 \mathrm{~s}$ belag used as the gams source. Use of this device permits 100 per cent nondestructive testing of the fuel elements. Prevlous methods requred destructive testing on a statistical basis.

The 256 Channel Analyzer in the 329 Bullaing was modifled for use by the Analytical Chemlistry Operation. The lateat 1mprovement, the thlrd made, consists of a method of shifting ata from half of the memory core to the other half. On low activity samples, the backeround count must be subtracted from the sample count. Before the modiflcation, tha backeround was taken after each sample count and subtracted. The modilication permits the background to be taken once a day and stored in hale of the memory core. After esch sample count, it ls shifted to the other half, subtracted and shifted back into storage. The modiflcation doubles the sample counting time of the instrument.

A micro sparik source unit was completed for use by the Analytjcal Laboratory Operation. Th1s instrument is capable of analyzing areas of 2 to 5 microns and will be used to study fuel element inclusions. It was designed by the Chemlcal Research Operation. 
Average steam generated (M Ibs/hr)

71.8
112.0
33,418
$3,676.64$
7.26
59.4
67.3

The actual plant efflciency rate wa low compared to theoretical efficiency and came as a result of the frequent boller changes necessitated by the construction work in the bullding. These changes were required to permit constmaction forces to wake equipment tie-ins to existing equipment.

The injection rate of the filming amine has been held at the initial. $5 \mathrm{ppm}$. This is to be continued until all evidence of the detergent action of the amine is eliminated. To date, no measurable amount of amine has been found in the bolier feed water indicating no carry-over to the boller from the deaerator.

On January 11, 1959 a large leak was detected in the new ground storage tank. The leak appeared to be between the wall and foundation in the northeast quadrant. Indications are that the floor at this location parted from the wall of the tank. This appears to have resulted erom undermining of the floor due to a leak in the drain sump. No action has been taken to date by the contractor to correct thla condition.

Stearn was provided to the 308 Builaing (PFPP) contractor on January 23, 1959. Thls was provided through a 1 " bypass line around the locked 6" supply vaive. A record of estirated steam consumption by the contractor is being maintained to allow subequent billing.

\section{PLAIII ENGINEERING}

There were 26 training classes held for crafts of HLO and FPD, representing 280 manhours of craft trainlng. 
FIRE PROTECTION, PREVENTION AND CIVII DEFENSE

Fire Responses

HAPO

Construction

Private

Outer Area

Fire Prevention Activities

Investigations

Property Damage Incldents

Fire Inspections

Hazard Recomendations

Fire Surveys, Pre-Fire Planning

$$
\begin{array}{cc}
\text { No. } & \text { Ioss } \\
5 & \text { None } \\
3 & \$ 287.32 \\
0 & \ldots \\
0 & \ldots
\end{array}
$$

\section{S1gnificant Fires}

On January 20, 1959 swing shift contractor personnel working the PRIR construction area discajted burning, swoking materlal that landed on a plle of concrete curling pads and canvas tarps. Then at 12:50 a.m., smoke was observed rising from the PRTR contalnment vessel by a patrolman who summoned Fire Protection personnel. The fire was located $60^{\prime}$ down on the inside of the vessel and was Just extending to the wood forms and shoring when discovered. It. was extinguished with essentialiy no loss to the Government.

On Januery 27, 1959 construction contractor personnel working in the 384 Building Addition allowed hot s.lag from an acetylene cutting torch to drop on unprotected cardboard cartons of pipe insulation. The flre was extinguished with no loss to the Government.

SAFETY, SECURITY AND RADIATION EXPEERIENCE

$\begin{array}{lc}\text { Medical Treatment Injuries } & 20 \\ \text { Frequency Rate } & 3.99 \\ \text { Disabling Injuries } & 0 \\ \text { Near Serious Accldents } & 0\end{array}$

There were no Security Violations reported.

There were no Radiation Occurrences reported. 
A possible invention has been made by $H . V$. Hermdon, Instmment \& Electrical Maintenance Operation. This device is a Creep Gauge for in-pile measurement. of materials. An Invention Report is being prepared.

\section{MEETINGS}

Round Table-Staff

Safety and Security

Information
26

31

13

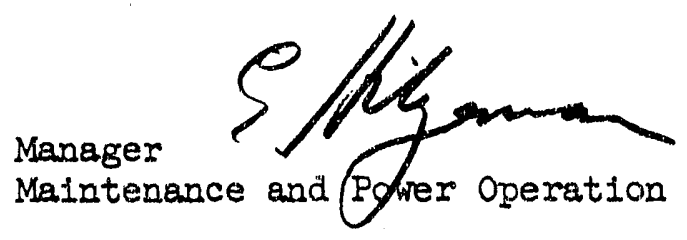

E. Hilgeman: JPF : mkm 


\section{EMPLOYES RELATIONS OPERATION}

January, 1959

SALARY AND IWAGE ADMINISTRATION

Appraisals resulting from the mass annual schedule are belng reviewed as received. In one case the description of performance did not support the appraisal number assigned and this fact was brought to the attention of the appraisor. He agreed to this analysis and revised the appraisal description.

An instruction $O P G$ on appraisal and salary review procedure was drafted. It is being further screened before issuance.

The Salary Plan Booklet was sent to one person new to G.E. and three other persons new to FPD were sent offers to discuss salary and appralsa. plan questions.

Data is being accumulated for four salary data and statistic studies as follows: (a) First Iine Supervisor Differential, (b) Employee Compensation Service Report No. 32--Company Exempt Salary Data, (c) ECS Report Nos. 502 and .507--Company Data on Technical College Graduate Compensation, and (d) Appra1sal and Salary Zope Match-Up. All studies should be completed and results reported by early February.

Although work loads of other departments affected scheduling, another lnternal. reconclilation meeting was held January 16,1959 w1th the four concerned departments (FPD, CPD, IPD \& R\&UO) represented. S1X FPD positions were internally reconciled and one position was judged to be unreconcilable on the high side. This information W11I be recorded and passed on to the concerned Level 3 Manager for appropriate further action.

The Savings \& Security Program increase of 2.5\%, effective January 1.5, 1959 has been recorded on the Employee Record cards of all participating Non-Bargalning Unit Bmployees.

Instructions covering nonexempt job description preparation were 1ssued. A few descriptions have reen recelved and scored. A matrix of 42 HAPO benchmark jobs has been formulated for Plant-wide evaluation to validate the proposed new salary structure and the job evaluation plan. Meanwhile study of alternative administrative guides is in progress.

All year end data reports, charts, etc. were issued on or before established deadIines. Included were: Salary Distribution Data, Exempt Measurement Report, Supervisory and Exempt Ratio Report, Organization Directory and Organizationel Polar Charts.

\section{PERSONNET DEVELOPMENT}

Seve persannel development programs were initiated, in progress or concluded during the month.

1. Sixteen employees began PBM-I.

2. Three employees carpleted PMS\&l, through R\&D Operation.

3. Six employees contimed the Creative Approach Seminars.

4. Eight emplojees contirued the Interviewing and Counseling course.

5. Six emplojees continued the refresher coorse in Solid State Physics. 
6. Eighteen enployees continued the Work Simplification course.

7. One exempt and three nonexempt Financial ermloyees started the Business Training Course Spring semester.

The Professional Supervisors Study Program, a long-range supervisory training program, was presented in outline form to the Manager-Maintenance and Power. Plans were laid for initiating one portion of this program for Area Maintenance supervisors during March.

Announcement of Spring personnel development courses to be of fered in the Department was distributed to all Fuels exempt persomel. In addition, detalled plans for personnel development activities through midyear were scoped.

Schectule for completion of all Exempt Personnel Development Review forms was communicated to each level 3 cormonent.

None of the six tech grad rotational assignments in Fuels were occupied during January. This was cue primarily to the reduced number of tech grads available in the program.

COMAONILATION

Draft of the 1958 FPD Report to Enplogees, a bookldt scheduled to be mailed to employees' homes in March, was campleted and appropriate approrals obtained.

Whe General Manager conducted two information meetings with nonexempt exployees and one with exenpt employees churing the month. A program of monthiy meetings with nonexempt employes was initiated by the Manager-Maintenance and Power.

During the month fire Management News Bulletins, two FPD Newsletters and one priority message were distributed. Other cammication activities included preparation of the Safety ropic and distribution of two reading rack booklets.

GE News coverage of FPD activities and enployees totaled 239 inches during Jamuary. Of this number, all but 11 inches were devoted to planned communication programs. The weekly average totaled approximately three-quarters of a GE News page per issue.

One speech was presented by a Departnent member on January 13 before the Milton-Freewater Rotary Club, and a group of Moxie, Washington, science students toured the 305 Test Reactor.

Movement of the boilier fram the 200 Area to the 300 Area is receiving international attention. A request for pictures and additional information was received from a free lance writer in Great Britain. 
Disabling Injuries

Serious Accidents

Medical Treatment Cases

Medical Treatment Frequency Rate

Employee Hours of Exposure

Orientation Presentations Attendance

Inspections

Suggestions Evaluated
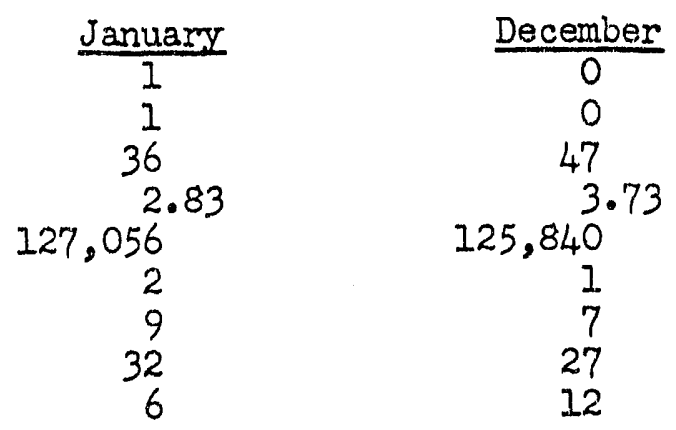

In January 1959, Department performance resulted in I Disabling Injury, I Serious Accident and 36 Medical Treatment Injuries. Total exposure hours accumulated at the time of injury amounted to 3,447,897 over a span of 857 days. The resulting frequency rate from September 1, 1956 through January 6, 1959 was 0.29 , and the severity rate for the same period was 1.45 .

\section{Program}

In January the Medical Treatment Frequency dropped to 2.83. There were 36 injuries reported of which $47 \%$ were sustained to the hands. Forty-seven percent of the hand injuries may have been prevented by proper use of gloves.

The regular monthly safety meeting for office employees was held on January 21. F. A. Leach conducted the meeting and presented an excellent demonstration on eye safety, entitled, "Let's Pretenit."

First Aid classes sponsored by the Program Council, to be conducted off the job, have been started with an initial response of approximately 33 participants. The course is the industrial first aid instruction of the State Department of Labor and Industries.

Safety awards were distributed to Department personnel on January 20 for the Presidentis Award, achieved on November 21, 1958.

Organization has been completed for the annual spring housekeeping and safety campaign, again titled "Operation New Broom." S. G. Forbes will serve as General Chairman.

Thirty-two facility inspections were conducted during January.

\section{Activities}

Job contacts with Manufacturing, Maintenance \& Power, and Engineering personnel during January included the following: Accident investigations, icing conditions, eye protection equipment, and zoned areas, hoisting apparatus, barricact, artificial resuscitation, materials handling, storage, safety mies and Job Hazard Breakdowns, housekeeping, pedestrian safety, equipment installation, safety standards, ventilation, guarding, publicity, lighting, chemicals, solvents, safety meetings, compressed gas systems, walks and roads, awards, medical schedules, automotive equipment, cranes, ladders, power equipment, electrical hazards, railroad right of ways, first aid, protective clothing, construction, control equipment, suggestions, explosives, air supply, high work, steam, staging and scaffolds, explosion proof equipment, and paintin, 
PERSONNEL PRACTICES

Employment

$\begin{array}{llll}\text { Personnel added: } \quad 6 & \text { Removed: } 7 & \\ \text { Reduction of force: } & \text { By seniority bumping } & 0 \\ & \text { By FPD } & 0\end{array}$

Transfer requests active at month end: 43

Procurement :

$\begin{array}{lllr}\text { Offers: } & 8 & \text { Requests for personnel: } & 16 \\ \text { Intervlews: } & 0 & \text { Transfers (all): } & 4\end{array}$

Upgrades with1n FPD: I

Attendance Awards: 5

Service Pins: $\quad 1$ - 10 year; 7 - 5 year

Employee Benefits and Service

Benefit Plans participation:

Pension: 100\% Savings and Security: $95.6 \%$

Insurance: $100 \%$

Stock Bonus: $49.3 \%$

Nonveteran employees subject to selective service:

13 in $1-A ; 5$ in 2-A; and 16 others. In addition there are:

5 technical occupational deferments active; 17 standby and 25 ready reservists; 2 employees on military leave.

Suggestion Plgn

$1-9-5-9$

January, 1959

Number of eligible employees

582

Nurnber of FPD suggestions recelved

62

Annualized rate per 1000 eliglble employees 1277

No. of suggestions adopted

Net annual savings

4

Arnount of awards

$\$ 41,3.19$

Percent of total awards to savings

$\$ 1,705$

Average amount of wards

$\$ \quad 426.25$

Year to Date

582

$62-$

1277

$\$ 41,319$

$\$ 1,705$

$\$ 426.25$ 
Technical Personnel Placement

\begin{tabular}{lrr} 
& January & FY 58 \\
\cline { 2 - 3 } & 14 & 329 \\
Openings referred to FPD & 4 & 33 \\
FPD candidates offered & 10 & 19 \\
PhD candidates referred to FPD & 4 & 43 \\
Other candidates referred to FPD & $?$ & 1 \\
Active transfer cases of FPD people & $:$ & 4 \\
Permenent assignment from Rotational Program & 0 &
\end{tabular}

\section{General}

Security Violations in the Department this month: 0

\section{UNION REIATIONS}

On January 16, 1959 the Company received an arbitration demand on the FPD $R$. W. Walters grievance (Instrument Worker situation). The Counc1l has been requested to submit additional information before a decision is made to arbitrate the case.

Union Relations Information Meetings princlpally for level 4 and 5 management of bargaining unit personnel were inaugurated on January 22.

Grievance Statistics

$\begin{array}{lr}\text { Received this month } & 12 \\ \text { Received since I/I/59 } & 12 \\ & \\ \text { Step I } & 0 \\ \text { Answer satisfactory } & 12 \\ \text { Answer unsatisfactory } & 10 \\ \text { Pending time limit to close } & 1 \\ \text { SEttled this morth } & \\ & 6 \\ \text { Step II } & 7 \\ \text { Discussed this month } & 2 \\ \text { Pending time limit to close } & 4 \\ \text { Settled this month } & \end{array}$


Grievance Statistics (Continued)

Subject of January Grievances

(Total 12)

Vacation

Jurisdiction

Transfer

Responsibility
Mfg. Eng. Maint. \& Emp. Fin.

Oper. Oper. Power Oper. Oper. Oper.

1

27

1

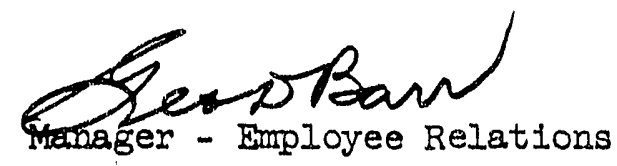

F-6 

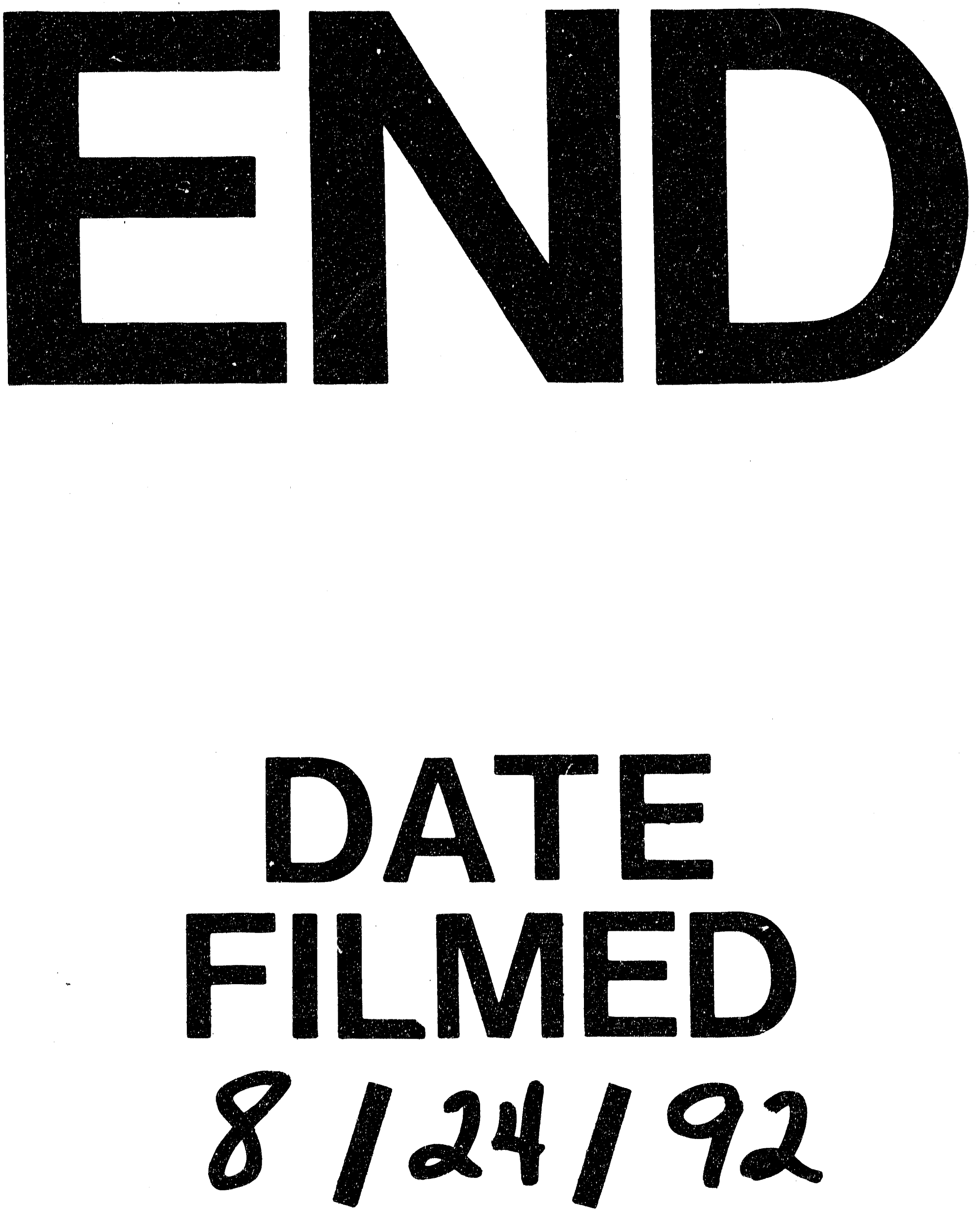